\title{
Data assimilation of satellite-retrieved ozone, carbon monoxide and nitrogen dioxide with ECMWF's Composition-IFS
}

\author{
A. Inness ${ }^{1}$, A.-M. Blechschmidt ${ }^{2}$, I. Bouarar ${ }^{3}$, S. Chabrillat ${ }^{4}$, M. Crepulja ${ }^{1}$, R. J. Engelen ${ }^{1}$, H. Eskes ${ }^{5}$, J. Flemming ${ }^{1}$, \\ A. Gaudel ${ }^{6,7}$, F. Hendrick ${ }^{4}$, V. Huijnen ${ }^{5}$, L. Jones ${ }^{1}$, J. Kapsomenakis ${ }^{8}$, E. Katragkou ${ }^{9}$, A. Keppens ${ }^{4}$, B. Langerock ${ }^{4}$, \\ M. de Mazière ${ }^{4}$, D. Melas ${ }^{10}$, M. Parrington ${ }^{1}$, V. H. Peuch ${ }^{1}$, M. Razinger ${ }^{1}$, A. Richter ${ }^{2}$, M. G. Schultz ${ }^{11}$, M. Suttie ${ }^{1}$, \\ V. Thouret ${ }^{6,7}$, M. Vrekoussis ${ }^{8,12}$, A. Wagner ${ }^{13}$, and C. Zerefos ${ }^{8}$ \\ ${ }^{1}$ ECMWF, Reading, UK \\ ${ }^{2}$ Institute of Environmental Physics, University of Bremen, Germany \\ ${ }^{3}$ Max Planck Institute for Meteorology, Hamburg, Germany \\ ${ }^{4}$ Belgian Institute for Space Aeronomy (BIRA-IASB), Brussels, Belgium \\ ${ }^{5}$ Royal Netherlands Meteorological Institute, De Bilt, the Netherlands \\ ${ }^{6}$ Université de Toulouse, UPS, LA (Laboratoire d'Aérologie), Toulouse, France \\ ${ }^{7}$ CNRS, LA (Laboratoire d'Aérologie), UMR 5560, 31400 Toulouse, France \\ ${ }^{8}$ Research Center for Atmospheric Physics and Climatology, Academy of Athens, Athens, Greece \\ ${ }^{9}$ Department of Meteorology and Climatology, School of Geology, Aristotle University of Thessaloniki, Thessaloniki, Greece \\ ${ }^{10}$ Laboratory of Atmospheric Physics, School of Physics, Aristotle University of Thessaloniki, Thessaloniki, Greece \\ ${ }^{11}$ Forschungszentrum Jülich, Jülich, Germany \\ ${ }^{12}$ Energy, Environment and Water Research Center (EEWRC), The Cyprus Institute, Nicosia, Cyprus \\ ${ }^{13}$ Deutscher Wetterdienst, Meteorologisches Observatorium Hohenpeissenberg, Germany
}

Correspondence to: A. Inness (a.inness@ecmwf.int)

Received: 22 December 2014 - Published in Atmos. Chem. Phys. Discuss.: 17 February 2015

Revised: 15 April 2015 - Accepted: 22 April 2015 - Published: 13 May 2015

\begin{abstract}
Daily global analyses and 5-day forecasts are generated in the context of the European Monitoring Atmospheric Composition and Climate (MACC) project using an extended version of the Integrated Forecasting System (IFS) of the European Centre for Medium-Range Weather Forecasts (ECMWF). The IFS now includes modules for chemistry, deposition and emission of reactive gases, aerosols, and greenhouse gases, and the 4-dimensional variational data assimilation scheme makes use of multiple satellite observations of atmospheric composition in addition to meteorological observations. This paper describes the data assimilation setup of the new Composition-IFS (C-IFS) with respect to reactive gases and validates analysis fields of ozone $\left(\mathrm{O}_{3}\right)$, carbon monoxide $(\mathrm{CO})$, and nitrogen dioxide $\left(\mathrm{NO}_{2}\right)$ for the year 2008 against independent observations and a control run without data assimilation. The largest improvement in $\mathrm{CO}$ by assimilation of Measurements of Pollution in the Troposphere (MOPITT) CO columns is seen in the lower tropo-
\end{abstract}

sphere of the Northern Hemisphere (NH) extratropics during winter, and during the South African biomass-burning season. The assimilation of several $\mathrm{O}_{3}$ total column and stratospheric profile retrievals greatly improves the total column, stratospheric and upper tropospheric $\mathrm{O}_{3}$ analysis fields relative to the control run. The impact on lower tropospheric ozone, which comes from the residual of the total column and stratospheric profile $\mathrm{O}_{3}$ data, is smaller, but nevertheless there is some improvement particularly in the $\mathrm{NH}$ during winter and spring. The impact of the assimilation of tropospheric $\mathrm{NO}_{2}$ columns from the Ozone Monitoring Instrument (OMI) is small because of the short lifetime of $\mathrm{NO}_{2}$, suggesting that $\mathrm{NO}_{2}$ observations would be better used to adjust emissions instead of initial conditions. The results further indicate that the quality of the tropospheric analyses and of the stratospheric ozone analysis obtained with the C-IFS system has improved compared to the previous "coupled" model system of MACC. 


\section{Introduction}

Air pollution has become the biggest environmental health risk, killing about 7 million people in 2012, according to a recent World Health Organization study (WHO, 2014). It is therefore important to provide air quality forecasts on global, regional and local scales to enable vulnerable people to take preventative action during pollution episodes. The Monitoring Atmospheric Composition and Climate (MACC) project (www.copernicus-atmosphere.eu) is the pre-operational atmospheric service of the European Copernicus programme funded by the European Commission's Framework Program 7 (FP7). MACC will evolve into the Copernicus Atmospheric Monitoring Service in 2015. MACC combines state-of-the art chemistry and transport models with satellite data from various sensors to provide consistent global analyses and forecasts of 3-dimensional fields of the atmospheric composition, including ozone $\left(\mathrm{O}_{3}\right)$, carbon monoxide $(\mathrm{CO})$, nitrogen dioxide $\left(\mathrm{NO}_{2}\right)$, sulphur dioxide $\left(\mathrm{SO}_{2}\right)$, formaldehyde $(\mathrm{HCHO})$, as well as methane $\left(\mathrm{CH}_{4}\right)$, carbon dioxide $\left(\mathrm{CO}_{2}\right)$ and aerosols (Flemming et al., 2013). The MACC- system is run routinely in near-real time (NRT) and provides daily 5-day forecasts of tropospheric and stratospheric composition at a horizontal resolution of about $80 \mathrm{~km}$ globally. For details of the system configuration, see http: //www.copernicus-atmosphere.eu/oper_info/. An earlier version of the system was also used to produce a 10-year reanalysis of atmospheric composition data covering the years 2003 to 2012 (Inness et al., 2013).

To improve the quality of the MACC forecasts the initial conditions for some of the chemical species $\left(\mathrm{O}_{3}, \mathrm{CO}\right.$, $\mathrm{NO}_{2}, \mathrm{SO}_{2}, \mathrm{CH}_{4}, \mathrm{CO}_{2}$, aerosols) are provided by data assimilation of atmospheric composition observations from satellites (Benedetti et al., 2009; Inness et al., 2013; Massart et al., 2014) in the MACC NRT systems. The use of data assimilation for atmospheric composition goes back almost 2 decades (Fisher and Lary, 1995; Elbern et al., 1997; Elbern and Schmidt, 1999, 2001; Lamarque et al., 1999; Khattatov et al., 2000, Ménard et al., 2000; Errera and Fonteyn, 2001). The overview articles by Carmichael et al. (2008) and Sandu and Chai (2011) describe the various approaches used for chemical data assimilation, including variational methods such as 3- and 4-dimensional variational (3D-Var and 4DVar) assimilation (e.g. Elbern and Schmidt, 2001; Chai et al., 2007; Errera et al., 2008, Hooghiemstra et al., 2011), Kalman Filters (e.g. Khattatov et al., 2000; Parrington et al., 2008, 2009) and Ensemble Kalman Filters (e.g. Arellano et al., 2007; Miyazaki et al., 2012b; Gaubert et al., 2014). Geer et al. (2006) compared different ozone analyses constructed using various assimilation techniques. The MACC system uses ECMWF's 4D-Var assimilation algorithm (Courtier et al., 1994). The variational methods aim to minimize a cost function that measures the difference between the model background field and the observations by adjusting chosen control variables in order to obtain the best possible forecast. Control variables can for example be the initial conditions (as done in the MACC and ECMWF system, e.g. Dragani, 2011), but also emission rates (Tanimoto et al., 2008; Miyazaki et al., 2012a) or other chemical parameters such as kinetic rate constants (Barbu et al., 2009).

While several of the initial studies concentrated on stratospheric ozone (e.g. Hólm et al., 1999; Khattatov et al., 2000; Eskes et al., 2002, 2003; Dethof and Hólm, 2004) data assimilation code has now also been implemented to assimilate tropospheric atmospheric composition data in both global and regional model systems (Lahoz et al., 2007; Zhang et al., 2012; Miyazaki et al., 2012b). Many studies still concentrate on ozone (e.g. Barré et al., 2014; Emili et al., 2014; Gaubert et al., 2014), but the assimilation of other species, such as CO (Yudin et al., 2004; Tangborn et al., 2009; Klonecki et al., 2012) and $\mathrm{NO}_{2}$ (Wang et al., 2011; Miyazaki et al., 2012a; Silver et al., 2013) is also being tested. Furthermore, some studies looked at the benefits obtained by the combined assimilation of several species (Hanea et al., 2004; Elbern et al., 2007; Miyazaki et al., 2012b).

Several of the studies listed above concentrated on case studies or were run for time periods of a few months at the most. As far as we are aware, the MACC system is the only system run routinely every day to provide global forecasts for atmospheric composition while using data assimilation to provide initial conditions for several species. Concerning reactive trace gases, which are the focus of this paper, the initial version of the MACC system (Hollingsworth et al., 2008) used a coupled setup (Flemming et al., 2009) in which the Model for OZone And Related chemical Tracers (MOZART3; Kinnison et al., 2007; Stein, 2009) chemical transport model (CTM) was coupled to ECMWF's Integrated Forecasting System (IFS) using the Ocean Atmosphere Sea Ice Soil coupling software (OASIS-4; Valcke and Redler, 2006). The main motivation for developing the coupled system was that the IFS data assimilation algorithm could be used for composition and Numerical Weather Prediction assimilation without the need to integrate complex chemistry schemes. However, this model setup was numerically expensive because of the overhead of the coupler and it did not scale well on ECMWF's supercomputer. Fields had to be interpolated between the IFS and CTM model grids and transport processes were duplicated. Experience during GEMS and MACC had shown that another disadvantage of the coupled system was that the chemical tendencies were unchanged during the 1-hour coupling intervals which could lead to problems at the day-night boundary for species with a short chemical lifetime. It was therefore decided to implement the chemistry scheme and its solvers directly in the IFS, together with modules for photolysis, wet and dry deposition, as well as emission injection, to create a more efficient model system called the Composition-IFS (C-IFS, Flemming et al., 2015). Of three candidate CTM versions available in MACC, the chemistry scheme of the Tracer Model 5 (TM5, Huijnen et al., 2010b) was implemented first, while C-IFS versions with 
MOZART and MOdèle de Chimie Atmosphérique à Grande Echelle (MOCAGE) have only become available recently. Therefore, this paper focuses on the analysis of data assimilation studies performed with C-IFS TM5, i.e. the model that is described in Flemming et al. (2015).

Flemming et al. (2015) showed that the current version of the on-line C-IFS implementation using the Carbon Bond Mechanism 5 (CB05, Yarwood et al., 2005) chemical mechanism performed better in forecast mode in many aspects than the previously used MOZART CTM version. Tropospheric $\mathrm{CO}$ biases were smaller in the Northern Hemisphere as were $\mathrm{O}_{3}$ biases in the upper troposphere. The diurnal cycle of surface ozone was also better represented in C-IFS. However, some problems remained with C-IFS, e.g. an overestimation of surface ozone in late summer and autumn. Tropospheric $\mathrm{CO}$ was still underestimated, particularly over Europe and North America, with the largest bias in winter and spring (see Stein et al., 2014, for a detailed discussion of this issue). $\mathrm{CO}$ was also underestimated over African biomass-burning areas. Furthermore, tropospheric $\mathrm{NO}_{2}$ was largely underestimated over eastern Asia during the winter. In this study we will show that by assimilating $\mathrm{O}_{3}, \mathrm{CO}$ and $\mathrm{NO}_{2}$ observations into C-IFS the analyzed fields show an improved representation of atmospheric composition.

This paper describes the C-IFS data assimilation setup and shows results from initial C-IFS assimilation experiments using $\mathrm{O}_{3}, \mathrm{CO}$ and $\mathrm{NO}_{2}$ satellite retrievals for the year 2008 . The resulting analysis fields are validated against independent observations and compared with global 3-dimensional fields from the MACC reanalysis (Inness et al., 2013) to assess how the C-IFS data assimilation system compares with the MACC coupled system. The paper is structured in the following way. Section 2 describes the C-IFS model and data assimilation system. Section 3 describes the experiment setup and the data used in the assimilation experiments. Section 4 shows results from the data assimilation experiments and validation against independent observations and fields from the MACC reanalysis. Section 5 finishes with conclusions and outlook.

\section{Description of the C-IFS model and data assimilation system}

\subsection{C-IFS model}

The current chemistry scheme implemented in C-IFS is a modified version of the $\mathrm{CB} 05$ chemical mechanism implemented in the TM5 CTM (Huijnen et al., 2010b, 2014; Williams et al., 2013). This is a tropospheric chemistry scheme with 54 species and 126 reactions. For stratospheric ozone the chemical tendencies above the tropopause are computed by a parameterization based on Cariolle and Teyssèdre (2007). Monthly mean dry deposition velocities are currently based on climatological fields from MOCAGE
(Michou et al., 2004). The module for wet deposition is based on the Harvard wet deposition scheme (Jacob et al., 2000; Liu et al., 2001).

This C-IFS system, called C-IFS (CB05) for the remainder of this paper, has been documented and extensively tested in forecast mode (Flemming et al., 2015; Huijnen et al., 2014). It has also run routinely as a CTM without data assimilation since November 2012 producing daily 5-day forecasts. A more detailed description of C-IFS (CB05) and the differences between it and the previously used coupled IFSMOZART system is given in Flemming et al. (2015).

The anthropogenic emissions used in the C-IFS runs described in this paper come from the MACCity emission data base (Granier et al., 2011), with increased winter-time road traffic $\mathrm{CO}$ emissions over North America and Europe according to an early version of the emission correction described by Stein et al. (2014). Biomass-burning emissions are provided by MACC's Global Fire Assimilation System (GFAS v1.0, Kaiser et al., 2012), and biogenic emissions are taken from the POET database for the year 2000 (Granier et al., 2005; Olivier et al., 2003), with isoprene emissions from MEGAN2.1, again for the year 2000 (Guenther et al., 2006). The emissions are injected at the surface and distributed over the boundary layer by the model's convection and vertical diffusion scheme.

\subsection{C-IFS data assimilation system}

The chemical species $\mathrm{O}_{3}, \mathrm{CO}, \mathrm{NO}_{2}, \mathrm{SO}_{2}$ and $\mathrm{HCHO}$ are incorporated into the ECMWF 4D-Var analysis as additional model variables and can be minimized together with the meteorological ECMWF control variables. $\mathrm{O}_{3}, \mathrm{CO}$, and $\mathrm{NO}_{2}$ are actively assimilated in the model runs described in this paper; i.e. they influence the initial conditions for these species, whereas $\mathrm{SO}_{2}$ and $\mathrm{HCHO}$ are only monitored passively and not discussed any further in this paper. $\mathrm{SO}_{2}$ data are only assimilated in the MACC system for volcanic eruptions (e.g. Flemming and Inness, 2013) and HCHO retrievals have large errors and are only used for monthly mean evaluation. At present, the background errors for the chemical species are univariate; i.e. the error covariance matrix between chemical species or between chemical species and dynamical fields is diagonal. Although Miyazaki et al. (2012b) have shown the benefit of including correlations between the background errors of different chemical species, this is not yet included in the C-IFS system. Hence, each compound is assimilated independently from the others. Furthermore, the coupling of tracers and wind field via the adjoint of the tracer continuity equation is also disabled. This restricts the impact of the tracer assimilation on the meteorological fields and allows us to develop the assimilation of the atmospheric composition data without degrading the meteorological analysis.

In the ECMWF data assimilation system the background error covariance matrix is given in a wavelet formulation (Fisher, 2004, 2006). This allows both spatial and spectral 

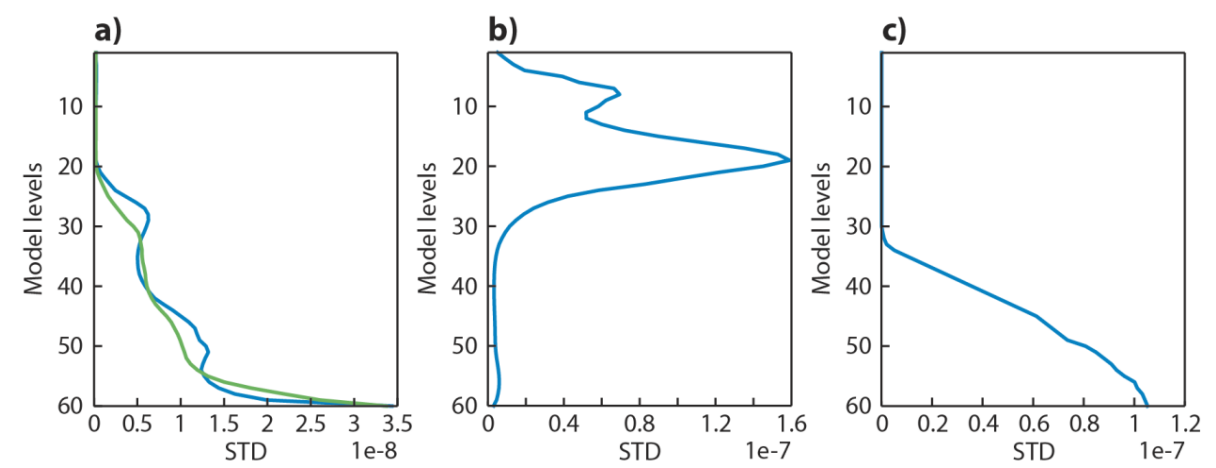

Figure 1. Background error SD profiles (blue) at $50^{\circ} \mathrm{N}, 10^{\circ} \mathrm{E}$ for (a) $\mathrm{CO}$ in kg kg${ }^{-1}$, (b) $\mathrm{O}_{3}$ in kg kg $\mathrm{kg}^{-1}$ and (c) $\log \left(\mathrm{NO}_{2}\right)$, dimensionless. Also shown in (a) is the profile for the CO background error SD of the original MACC system used in REAN (green).

variations of the horizontal and vertical background error covariances. The MACC background errors are constant in time. The background errors for $\mathrm{O}_{3}$ and $\mathrm{NO}_{2}$ used in the $\mathrm{C}$-IFS experiments are based on the ones used in the coupled MACC system (see Inness et al., 2009, 2013), while the background errors for $\mathrm{CO}$ are newly calculated for the C-IFS data assimilation runs from an ensemble of C-IFS forecast runs that contained 10 members with perturbations to the model physics, observations, sea surface temperatures and emissions. Differences between pairs of background fields were calculated which have the statistical characteristics of the background errors. It is planned to recalculate all the background error statistics with the latest version of C-IFS and test these in further assimilation experiments.

The vertical correlations of the $\mathrm{O}_{3}$ and $\mathrm{CO}$ background errors were restricted to five model levels below and above a level to decouple the lower troposphere from the upper troposphere and stratosphere. This corresponds to a physical difference of about $0.2-1 \mathrm{~km}$ in the lower troposphere, $1-2 \mathrm{~km}$ in the mid-troposphere and about $3 \mathrm{~km}$ in the upper troposphere. The reason for this was that the original background errors had vertical correlations between the upper troposphere/stratosphere and near-surface levels that degraded lower tropospheric ozone when there was a bias in stratospheric ozone. By limiting the vertical correlations to the neighbouring levels this degradation was avoided.

In the MACC system a logarithmic control variable is used for $\mathrm{NO}_{2}$, because if the analysis were based on a linear mixing ratio scale it would be prone to large extrapolation errors, due to the high variability of $\mathrm{NO}_{2}$ in space and time and the difficulties in modelling the error covariances. The $\mathrm{NO}_{2}$ background errors were designed to be practically zero in the stratosphere, because only tropospheric $\mathrm{NO}_{2}$ columns are assimilated in this study and the influence of the assimilation is designed to be limited to the troposphere. The vertical correlation matrix for $\mathrm{NO}_{2}$ is diagonal; i.e. there are no correlations between neighbouring levels. Profiles of the standard deviation (SD) of the background errors for $\mathrm{CO}, \mathrm{O}_{3}$ and $\mathrm{NO}_{2}$ are shown in Fig. 1.
The observation error and background error covariance matrices determine the relative weight given to the observations and the background in the analysis. The C-IFS observation error covariance matrix is diagonal; i.e. the observation errors are assumed to be uncorrelated in the vertical and horizontal. By assimilating partial columns we hope to avoid vertical error correlations. For the chemical observations, observation error values given by the data providers are used. A minimum value of $5 \%$ is used to include any observation operator error and a representativeness error that could arise because of differences in resolution of observation and the model, and that accounts for scales unresolved by the model. This minimum value will need to be reassessed as the model improves and new observational data sets become available.

Observation operators are needed to calculate the model equivalent of the assimilated observations, i.e. of satellite retrievals of the atmospheric composition. The $\mathrm{O}_{3}, \mathrm{CO}$ and $\mathrm{NO}_{2}$ observations used in the IFS are total or partial column data, i.e. integrated layers bounded by a top and a bottom pressure. The model's background values are either calculated as a simple vertical integral between the top and the bottom pressure levels or by using averaging kernels if these are provided in the data to give the partial or total columns at the time and location of the observations (see also Inness et al., 2013). More information about the assimilated data sets is given in Sect. 3.2 below.

\section{Experiment setup and data}

\subsection{Experiments}

To test C-IFS (CB05) in data assimilation mode two experiments were run for the year 2008: an assimilation run (CIFSAN) in which $\mathrm{O}_{3}, \mathrm{CO}$ and $\mathrm{NO}_{2}$ satellite retrievals (see Table 1) were assimilated in addition to the available meteorological data, and a control run (CIFS-CTRL) in which only the meteorological data were assimilated. The underlying $\mathrm{C}$ IFS (CB05) model is identical to the setup described in Flemming et al. (2015) apart from the anthropogenic emissions 
which were the original MACCity emissions in their runs, i.e. with no adjustment of $\mathrm{CO}$ emissions. Both experiments were initialized with data from a C-IFS forecast for $31 \mathrm{De}-$ cember 2007, run at a horizontal resolution of about $80 \mathrm{~km}$ (T255 horizontal truncation), and had 60 model levels between the surface and $0.1 \mathrm{hPa}$.

All observations were assimilated in $12 \mathrm{~h}$ assimilation windows (09:00-21:00 UTC, 21:00-09:00 UTC), in which two minimizations were run at T95 and T159 corresponding to horizontal resolutions of about 210 and $120 \mathrm{~km}$, respectively. The first minimization is run with simplified physics, while the second minimization is performed with improved physics after an update of the model trajectory at high resolution (Mahfouf and Rabier, 2000). Because the physics parameterizations are computationally expensive, the second update carries out fewer iterations of minimization than the first. $12 \mathrm{~h}$ assimilation windows are the standard setup of the ECMWF system at present, and it will have to be assessed in further studies if this window length is ideal for the MACC system, or if a shorter window would be better for the assimilation of shorter lived species. The experiments used IFS model cycle CY40R1; see documentation at http: //nwmstest.ecmwf.int/research/ifsdocs/CY40r1/ and https:// software.ecmwf.int/wiki/display/IFS/Operational+changes.

\subsection{Satellite data used in the experiments}

Table 1 shows the atmospheric composition retrievals for $\mathrm{CO}, \mathrm{O}_{3}$ and $\mathrm{NO}_{2}$ that were assimilated in CIFS-AN. Averaging kernels were used for the calculation of the model's first-guess fields in the observation operators (see Inness et al., 2013) where available, i.e. for CO data (thermal infrared retrieval product) from the Measurements of Pollution in the Troposphere (MOPITT) instrument and $\mathrm{NO}_{2}$ data from the Ozone Monitoring Instrument (OMI). Background quality checks and variational quality control (Andersson and Järvinen, 1999) were applied to all atmospheric composition data. The background quality check rejected observations if the square of the normalized background departure was greater than 5 , while the variational quality control reduced the weight of observations that had large departures but still passed the first-guess check. Data flagged as "bad" by the data providers were discarded.

The satellite retrievals of atmospheric composition, which passed all these quality checks, were thinned to a horizontal resolution of $1^{\circ} \times 1^{\circ}$ by randomly selecting an observation in the grid box to avoid oversampling and spatially correlated observation errors. A possible limitation of this thinning method is that it might lead to the assimilation of noisy or unrepresentative observations in areas of low background concentrations or to representativeness errors over polluted areas where the true state might be very heterogeneous. However, tests carried out assimilating MOPITT CO data averaged on a $1^{\circ} \times 1^{\circ}$ grid (not shown in this paper) gave very similar results to assimilating the thinned MOPITT CO data, giving us confidence that our thinning method performs well. The assimilation of averaged $\mathrm{NO}_{2}$ "super-observations" will be tested in the future.

Variational bias correction (Dee and Uppala, 2009) was applied to ozone column data from the OMI and the SCanning Imaging Absorption spectroMeter for Atmospheric CHartographY (SCIAMACHY), while the partial column Solar Backscatter UltraViolet (SBUV/2), and profile Microwave Limb Sounder (MLS) and Michelson Interferometer for Passive Atmospheric Sounding (MIPAS) data were used to anchor the bias correction; i.e. they were assimilated without bias correction. Experience from the MACC reanalysis has shown that it is important to have an anchor for the bias correction, to avoid drifts in the fields (Inness et al., 2013). The SBUV/2 data were chosen as anchor because they are a high quality reprocessed data set. The MLS and MIPAS profile data were not bias corrected because experience in REAN had shown that the SBUV/2 data could not anchor all the layers of the higher resolved profile data and that drifts in individual layers could lead to problems in the vertical $\mathrm{O}_{3}$ distribution (Inness et al., 2013). For $\mathrm{CO}$ and $\mathrm{NO}_{2}$ data no bias correction was applied in CIFS-AN because data from only one instrument were assimilated and it was not possible to anchor the variational bias correction.

\subsection{Evaluation data}

The two experiments CIFS-AN and CIFS-CTRL, as well as fields from the MACC reanalysis (REAN, Inness et al., 2013), are compared against each other and independent observations that were not used in either CIFS-AN and REAN. Initial evaluation results from REAN are shown in Inness et al. (2013), and more detailed evaluation can be found in the MACC reanalysis validation reports available from http://www.copernicus-atmosphere.eu/services/ aqac/global_verification/validation_reports/. It should be noted that the configurations of REAN and CIFS-AN are different because the underlying chemical model and some of the assimilated data sets have changed (see Table S1 in the Supplement and also Inness et al., 2013). For example, CO retrievals from the Infrared Atmospheric Sounding Interferometer (IASI) were assimilated in REAN in addition to MOPITT CO columns when they became available from April 2008 onwards, which led to a pronounced change in the $\mathrm{CO}$ analysis fields. To avoid such a change in the 2008 C-IFS experiments only MOPITT retrievals are assimilated in CIFS-AN.

Several of the differences between CIFS-AN and REAN (for example differences in the chemical mechanisms, the biomass-burning emissions, the dry deposition velocity fields, and an enhancement factor for traffic $\mathrm{CO}$ emissions in C-IFS) are likely to have an impact in the lower troposphere, where the sensitivity of the assimilated satellite data is low. Nevertheless, it is useful to compare CIFS-AN with REAN because REAN is a documented and widely used data set 
Table 1. Atmospheric composition satellite retrievals that were used in CIFS-AN. PROF denotes profile data, TC total columns, TRC tropospheric columns, PC partial columns, and SOE solar elevation. PC SBUV/2 data consist of six layers between the surface and $0.1 \mathrm{hPa}$.

\begin{tabular}{|c|c|c|c|c|c|c|}
\hline Sensor & Satellite & Provider & Version & Type & Data usage criteria & Reference \\
\hline MIPAS & ENVISAT & KIT & CCI, V220 & $\mathrm{O}_{3} \mathrm{PROF}$ & All data used & von Clarmann et al. $(2003,2009)$ \\
\hline MLS & AURA & NASA & V02 & $\mathrm{O}_{3} \mathrm{PROF}$ & All data used & Waters et al. (2006) \\
\hline OMI & AURA & NASA & V003 & $\mathrm{O}_{3} \mathrm{TC}$ & Used if $\mathrm{SOE}>10^{\circ}$ & $\begin{array}{l}\text { Bhartia and Wellemeyer (2002); } \\
\text { Levelt et al. (2006) }\end{array}$ \\
\hline SBUV/2 & NOAA-16 & NOAA & V8 & $\mathrm{O}_{3} \mathrm{PC}$ & Used if $\mathrm{SOE}>6^{\circ}$ & Bhartia et al. (1996) \\
\hline SBUV/2 & NOAA-17 & NOAA & V8 & $\mathrm{O}_{3} \mathrm{PC}$ & Used if $\mathrm{SOE}>6^{\circ}$ & Bhartia et al. (1996) \\
\hline SBUV/2 & NOAA-18 & NOAA & V8 & $\mathrm{O}_{3} \mathrm{PC}$ & Used if $\mathrm{SOE}>6^{\circ}$ & Bhartia et al. (1996) \\
\hline SCIAMACHY & ENVISAT & BIRA & CCI, fv0100 & $\mathrm{O}_{3} \mathrm{TC}$ & Used if $\mathrm{SOE}>6^{\circ}$ & van Roozendael et al. (2012) \\
\hline MOPITT & TERRA & NCAR & V5 & $\mathrm{CO} \mathrm{TC}$ & $\begin{array}{l}\text { Used if } \\
65^{\circ} \mathrm{S}<\text { lat }<65^{\circ} \mathrm{N}\end{array}$ & Deeter et al. $(2010,2013)$ \\
\hline OMI & AURA & KNMI & V1.1 & $\mathrm{NO}_{2} \mathrm{TRC}$ & $\begin{array}{l}\text { Used if } \mathrm{SOE}>6^{\circ} \text { and } \\
60^{\circ} \mathrm{S}<\text { lat }<60^{\circ} \mathrm{N}\end{array}$ & $\begin{array}{l}\text { http://www.temis.nl, } \\
\text { Wang et al. (2008) }\end{array}$ \\
\hline
\end{tabular}

Table 2. Summary of validation data sets used in this study. A more comprehensive description of the data sets can be found in the Supplement.

\begin{tabular}{|c|c|c|c|}
\hline Data set & Validated fields & Uncertainty & References \\
\hline MOZAIC & $\begin{array}{l}\text { CO profiles at Frankfurt } \\
\text { ( } 837 \text { profiles }) \text { and Wind- } \\
\text { hoek ( } 323 \text { profiles })\end{array}$ & $\begin{array}{l}\text { Uncertainty: } \pm 5 \mathrm{ppbv} \\
\text { Precision: } \pm 5 \% \\
\text { Detection limit: } 10 \mathrm{ppbv}\end{array}$ & $\begin{array}{l}\text { Marenco et al. (1998) } \\
\text { Nedelec et al. (2003) }\end{array}$ \\
\hline NDACC FTIR & $\begin{array}{l}\mathrm{CO} \text { profiles and tropo- } \\
\text { spheric columns (see } \\
\text { Table S2 for list of stations) }\end{array}$ & $\begin{array}{l}\text { Uncertainty (smoothing uncer- } \\
\text { tainty not included): } \\
\text { Trop. columns 5-9\% } \\
\text { Individual levels: } 10-25 \%\end{array}$ & $\begin{array}{l}\text { Dils et al. (2006) } \\
\text { De Laat et al. (2010) } \\
\text { Langerock et al. (2015) }\end{array}$ \\
\hline GAW & $\begin{array}{l}\text { Surface } \mathrm{CO} \text { (see Table S3) } \\
\text { and } \mathrm{O}_{3} \text { (see Table S4) }\end{array}$ & $\begin{array}{l} \pm 2-5 \mathrm{ppbv}(\mathrm{CO}) \\
\pm 1 \mathrm{ppbv}\left(\mathrm{O}_{3}\right)\end{array}$ & $\begin{array}{l}\text { Oltmans and Levy (1994) } \\
\text { Novelli and Masarie (2014) }\end{array}$ \\
\hline Multi Sensor Reanalysis & Total column $\mathrm{O}_{3}$ (TCO3) & $\sim 1 \mathrm{DU}$ & Van der A et al. (2010) \\
\hline ACE-FTS & Stratospheric $\mathrm{O}_{3}$ profiles & $\begin{array}{l}\text { Bias < } 5 \%(15-45 \mathrm{~km}) \\
\text { Precision: } \\
12-15 \% \text { above } 20 \mathrm{~km} \\
17-30 \% \text { below } 20 \mathrm{~km}\end{array}$ & Dupuy et al. (2009) \\
\hline MIPAS & Stratospheric $\mathrm{O}_{3}$ profiles & $\begin{array}{l}5-10 \% \text { (larger near boundaries } \\
\text { of retrieval range) }\end{array}$ & Raspollini et al. (2013) \\
\hline Ozonesondes & $\mathrm{O}_{3}$ profiles & $\begin{array}{l}-14 \text { to } 16 \% \text { above } 10 \mathrm{hPa} \\
5 \% \text { between } 200-10 \mathrm{hPa} \\
-7 \text { to } 17 \% \text { below } 200 \mathrm{hPa}\end{array}$ & $\begin{array}{l}\text { Komhyr et al. (1995) } \\
\text { Steinbrecht et al. (1998) }\end{array}$ \\
\hline GOME-2 & $\begin{array}{l}\text { Tropospheric } \mathrm{NO}_{2} \text { columns } \\
\text { (TRCNO2) }\end{array}$ & $\pm 20-30 \%$ & Richter et al. (2011) \\
\hline MAX-DOAS at Beijing & $\mathrm{NO}_{2}$ profiles & $12 \%$ & Hendrick et al. (2014) \\
\hline
\end{tabular}

produced with the coupled MACC system that can serve as a benchmark for the evaluation of CIFS-AN.

Table 2 lists the data sets used in this paper for the evaluation of $\mathrm{CO}, \mathrm{O}_{3}$ and $\mathrm{NO}_{2}$ fields. More detailed information about the evaluation data sets can be found in the Supplement.

\section{Results}

This section presents results from the C-IFS experiments highlighting the impact of the assimilation of satellite data on the $\mathrm{CO}, \mathrm{O}_{3}$ and $\mathrm{NO}_{2}$ fields in CIFS-AN. 


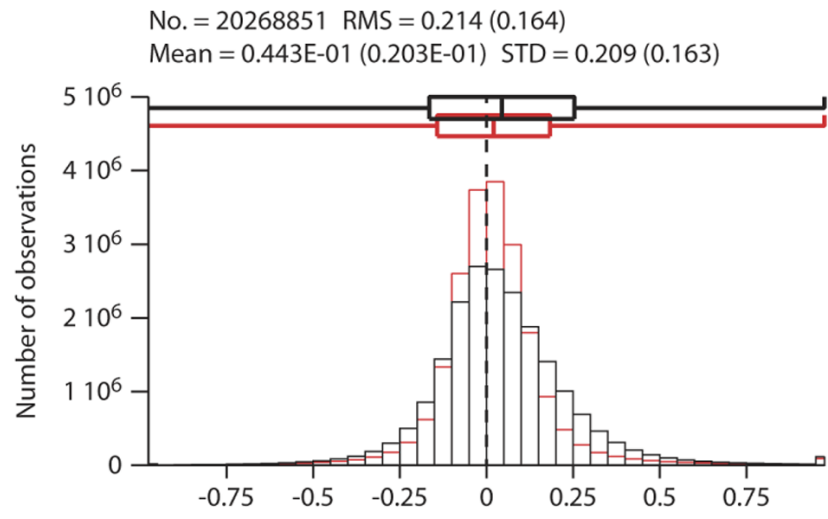

looking at the distribution of analysis departures (i.e. observation minus analysis (obs-an) values) in the form of histograms from CIFS-AN and CIFS-CTRL for 2008, for all MOPITT data that were flagged as good quality by the data producers (Fig. 2). Note that in CIFS-CTRL the MOPITT TCCO data were included passively in the analysis, so that the departures statistics could be calculated. Figure 2 shows that the analysis is drawing to the MOPITT data and the biases with respect to MOPITT are more than halved in all regions compared to CIFS-CTRL. The values of the annual mean departures (listed in Fig. 2), their root mean square (RMS) and SD for the $\mathrm{NH}$, tropics and $\mathrm{SH}$ show that there are reductions in all these diagnostics in all areas. The plots also show that CIFS-CTRL underestimates $\mathrm{CO}$ in the NH compared to MOPITT (obs-an >0) and overestimates CO (obsan $<0$ ) in the tropics and SH. This is in agreement with what was found for C-IFS (CB05) forecast runs by Flemming et al. (2015).

The seasonal mean TCCO analysis increments (analysis minus forecast values) and a time series of zonal mean TCCO analysis increments are shown in the supplementary material (Figs. S1 and S2). They illustrate where the assimilation reduces or increases the TCCO field. It should be noted that after a large initial correction (Fig. S2) the TCCO increments are small: less than $1 \%$ in the zonal mean and less than $4 \%$ in the seasonal means. This illustrates that the analysis is drawing to the TCCO data and that the information brought into the analysis by the data is maintained and carried over into the subsequent analysis cycles.

Figure 3 shows zonal mean time series of MOPITT TCCO data which are used in CIFS-AN between $65^{\circ} \mathrm{N}$ and $65^{\circ} \mathrm{S}$, MOPITT analysis departures from CIFS-AN and CIFSCTRL, and differences between the experiments. The analysis departures are small in CIFS-AN, while they show an overestimation in CIFS-CTRL in the NH and an underestimation in the tropics and $\mathrm{SH}$ (as already noted in Fig. 2). The assimilation increases TCCO at high northern latitudes in winter and spring, when the CO lifetime is longest, and reduces it in the tropics throughout the year. This is also confirmed in Fig. 4 which shows the seasonal mean vertical differences between CIFS-AN and CIFS-CTRL. In all seasons, $\mathrm{CO}$ is reduced in the tropics throughout the troposphere and in the mid and upper troposphere in the SH. It is also reduced in the upper troposphere of the NH in March, April, May (MAM), June, July, August (JJA) and September, October, November (SON). CO is increased below $400 \mathrm{hPa}$ in the NH extratropics in January and February (JF), MAM and SON and in the SH in MAM, JJA and SON, with the largest increases in the boundary layer. In JJA, the biggest increase in the $\mathrm{NH}$ is seen around $400 \mathrm{hPa}$, where MOPITT has the largest sensitivity.

It should be noted that even though TCCO data are assimilated in CIFS-AN, transport processes lead to a change in the vertical CO profiles. The assimilation of TCCO data leads to increased $\mathrm{CO}$ columns in the extratropics and to decreased 

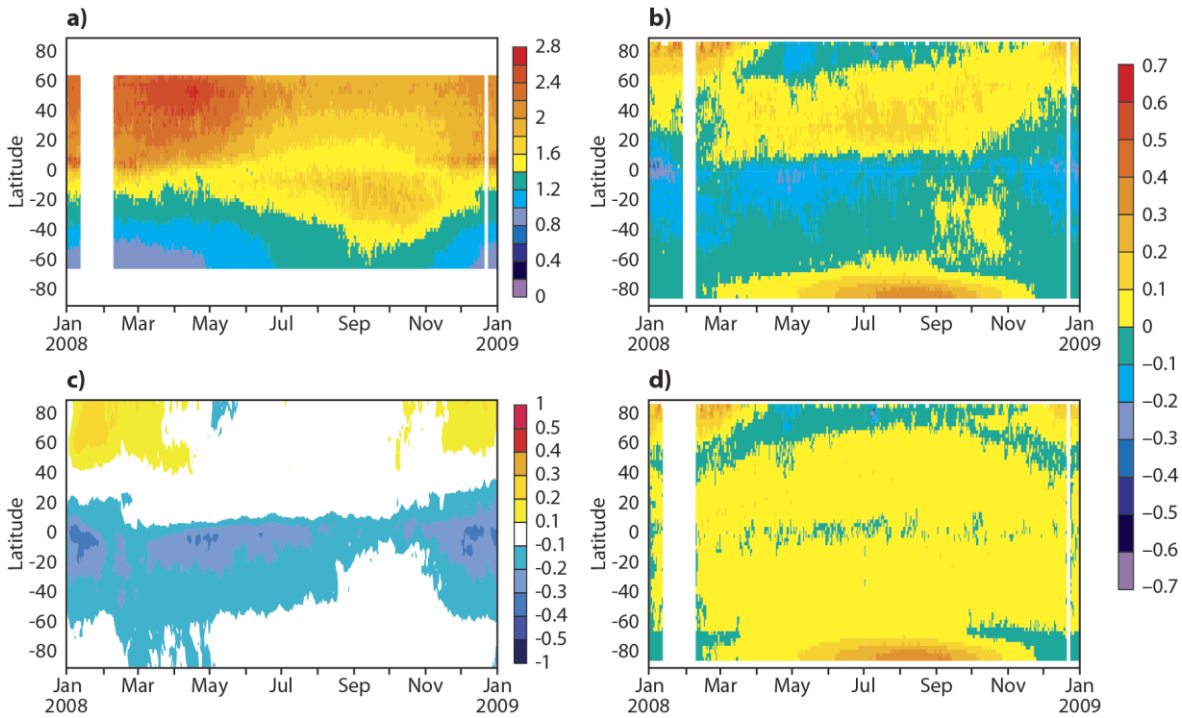

Figure 3. Time series of (a) zonal mean TCCO from the MOPITT data used in CIFS-AN, (b) TCCO analysis departures (observations minus analysis) from CIFS-CTRL and (d) TCCO analysis departures from CIFS-AN, all in $10^{18}$ molecules $\mathrm{cm}^{-2}$. Shown in (c) is the zonal mean relative difference in \% of CIFS-AN minus CIFS-CTRL. In (a) red indicates higher values of the field, blue lower values. In (b)-(d) red indicates positive values, blue negative values.
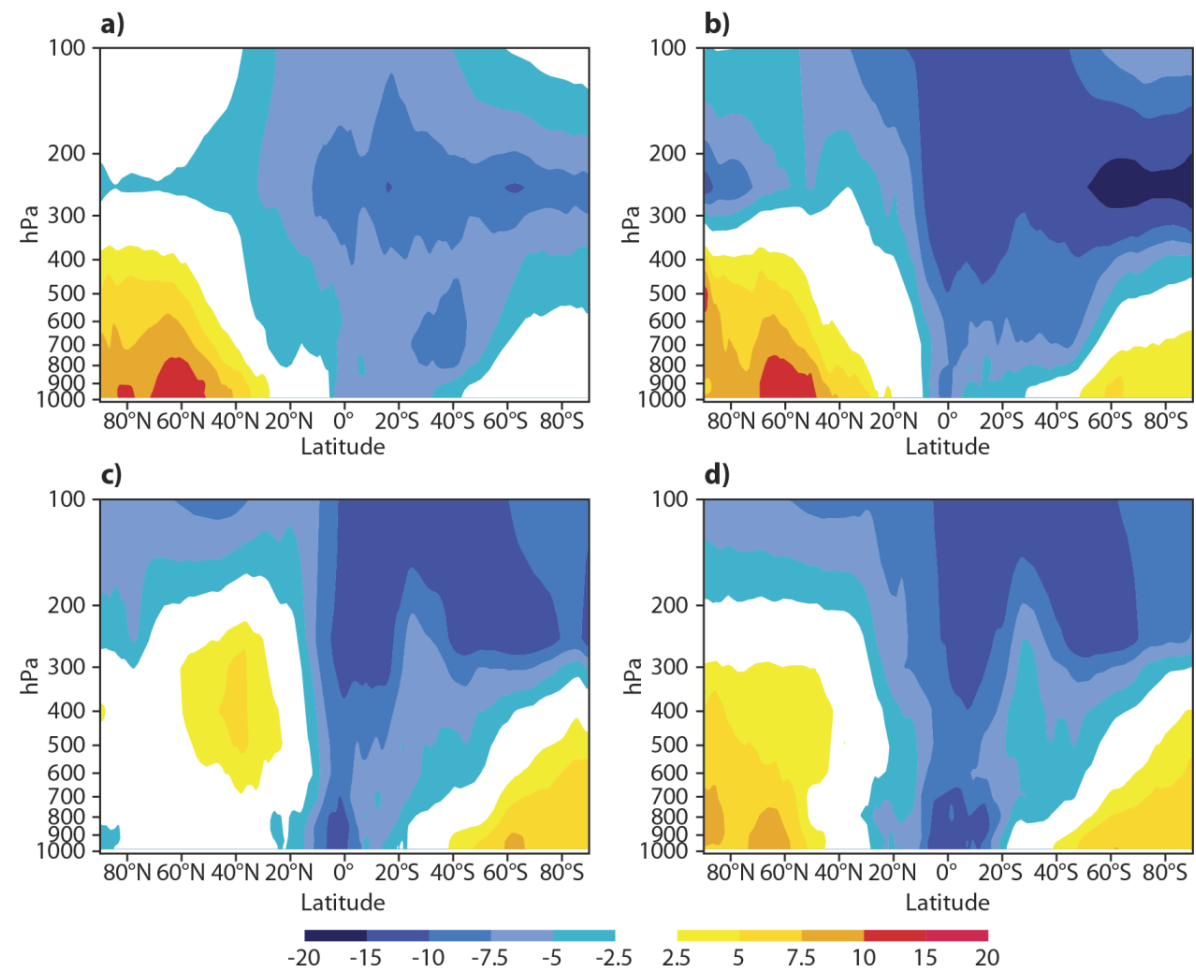

Figure 4. Cross sections of the seasonal mean zonal mean CO differences between CIFS-AN minus CIFS-CTRL in ppb for (a) JF, (b) MAM, (c) JJA and (d) SON 2008. Red indicates positive values, blue negative values.

CO columns in the tropics (Fig. 2) with corresponding positive and negative analysis increments throughout the troposphere. Poleward transport from the tropics in the upper tro- posphere then leads to the lower CO concentrations in the extratropical upper troposphere in CIFS-AN seen in Fig. 4.

The most likely reason for the underestimation of $\mathrm{CO}$ in CIFS-CTRL in the NH extratropics is an underestimation of 
a)

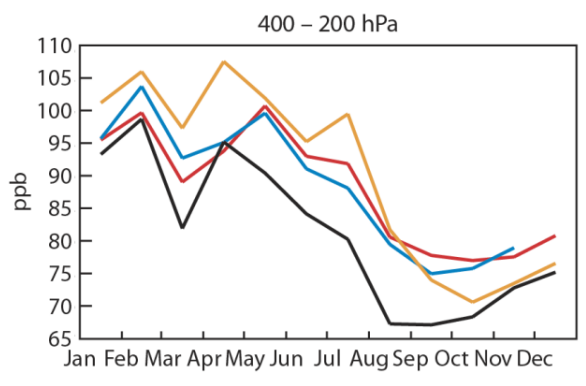

$700-400 \mathrm{hPa}$

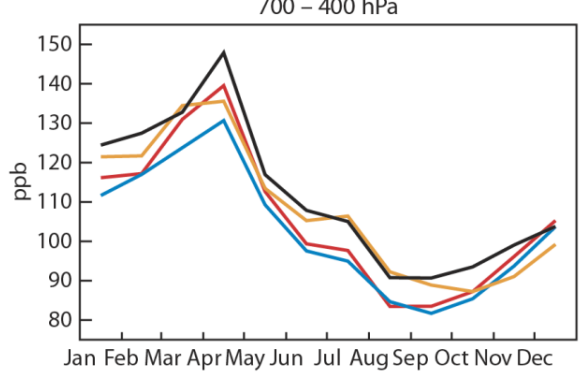

Jan Feb Mar AprMay Jun Jul Aug Sep Oct Nov Dec

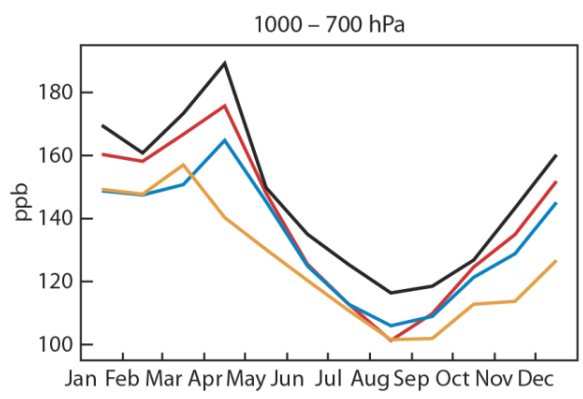

b)

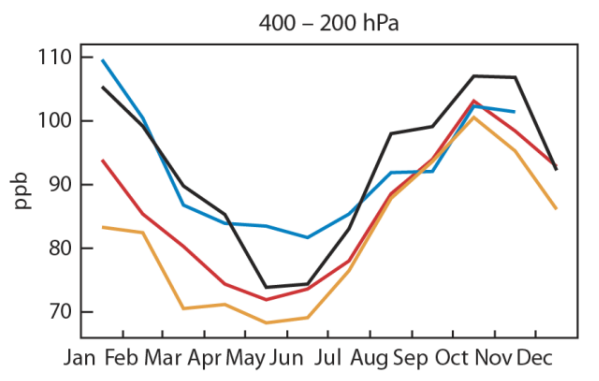

$700-400 \mathrm{hPa}$

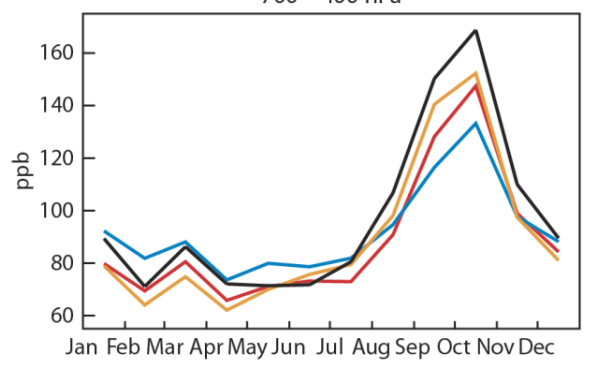

$1000-700 \mathrm{hPa}$

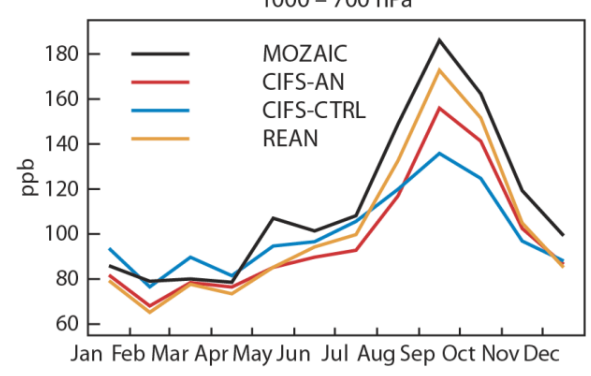

Figure 5. Time series of monthly mean tropospheric $\mathrm{CO}$ in ppb over (a) Frankfurt $\left(50^{\circ} \mathrm{N}, 8.6^{\circ} \mathrm{E}, 837\right.$ profiles) and (b) Windhoek $\left(22.5^{\circ} \mathrm{S}\right.$, $17.5^{\circ} \mathrm{E}, 323$ profiles) averaged in the pressure bands $1000-700 \mathrm{hPa}$ (bottom), $700-400 \mathrm{hPa}$ (middle) and 400-200 $\mathrm{hPa}$ (top) from MOZAIC aircraft data (black), CIFS-AN (red), CIFS-CTRL (blue) and REAN (orange) in 2008.

the anthropogenic emissions. This is also discussed in Flemming et al. (2015). It should be noted that low CO values are found by most of the CTMs regardless of the emission inventory used (e.g. Shindell et al., 2006; Kopacz et al., 2010; Fortems-Cheiney et al., 2011) and that the MACCity anthropogenic emissions are in the same range as the emissions provided by the few other emission inventories available for the post-2000 period (Granier et al., 2011). A possible reason for the general overestimation of $\mathrm{CO}$ in the tropics could be too large GFAS biomass-burning emissions (Flemming et al., 2015). The only exception is the strong underestimation of $\mathrm{CO}$ in the biomass-burning maximum in southern Africa, which points to an underestimation of the GFAS biomassburning emissions in that area (see Fig. 5 below).

\subsubsection{CO evaluation against independent observations}

Figure 5 shows time series of monthly mean $\mathrm{CO}$ from MOZAIC aircraft data and the three experiments averaged over the lower troposphere (LT, $1000-700 \mathrm{hPa}$ ), the mid- troposphere (MT, 700-400 hPa) and the upper troposphere (UT, 400-200 hPa) near Frankfurt and Windhoek airport. At Frankfurt, which has the largest number of profiles per month of all MOZAIC airports, all experiments manage to reproduce the seasonal cycle seen in the observations with highest $\mathrm{CO}$ values at the end of northern spring due to the longer lifetime of $\mathrm{CO}$ and higher anthropogenic emissions during winter and spring. CIFS-CTRL underestimates CO in the LT and MT throughout the year with the largest bias of between 20 and 40 parts per billion (ppb) in the LT during the winter months, when $\mathrm{CO}$ concentrations are highest. In the UT, CIFS-CTRL overestimates CO. This was also noticed in the stand-alone C-IFS runs described by Flemming et al. (2015).

The assimilation of MOPITT TCCO data improves the fit to the MOZAIC data by increasing CO in the LT and MT and reducing it in the UT during the winter and spring months. This change agrees with the zonal mean differences seen between CIFS-AN and CIFS-CTRL in Fig. 4 and illustrates that assimilating total column $\mathrm{CO}$ data can help to improve the vertical structure of the CO field by applying a $4 \mathrm{D}$-Var 

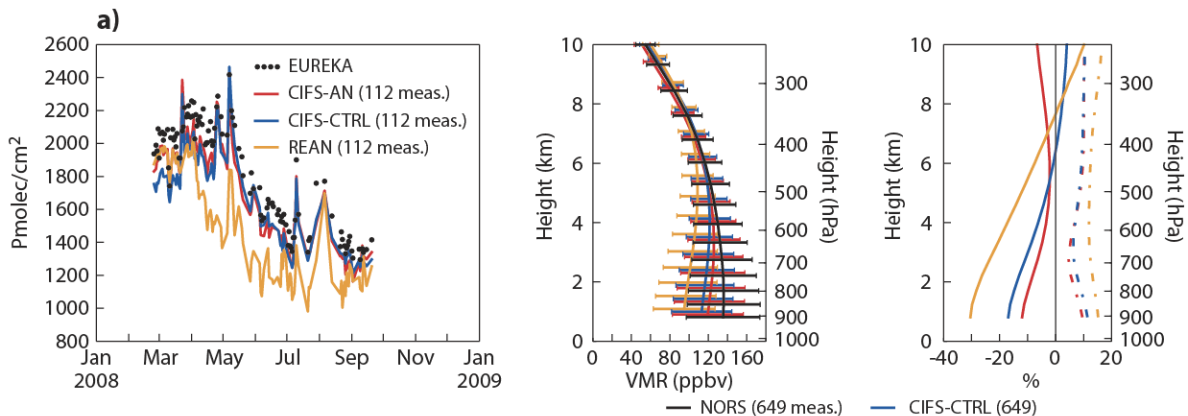

b)
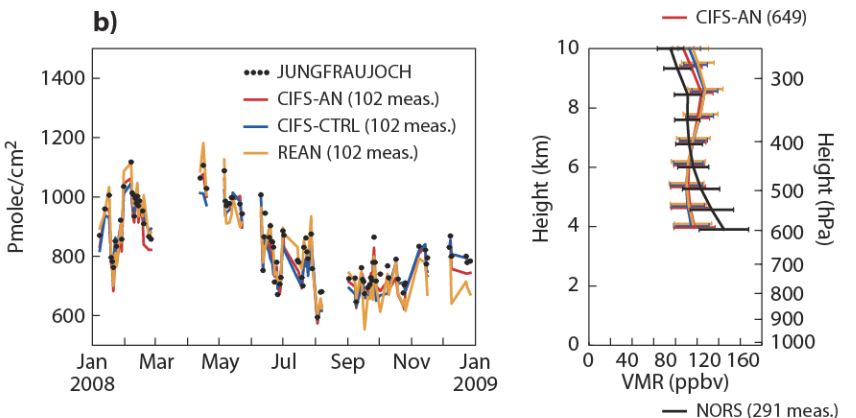

- CIFS-CTRL (649)

- REAN (649)

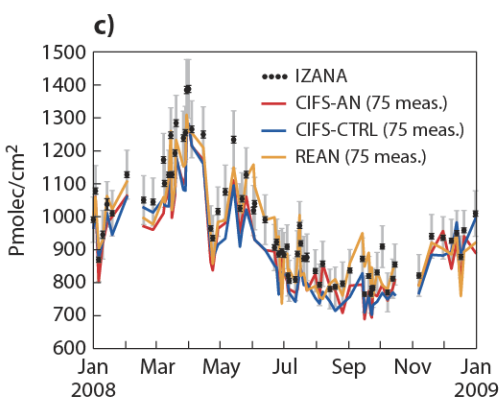

- CIFS-AN (291)
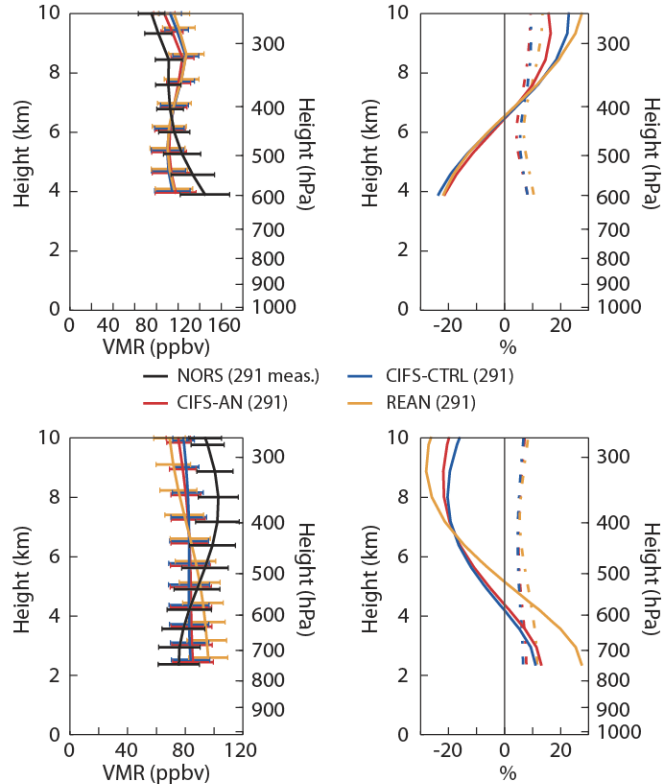

- CIFS-CTRL (291)

- REAN (291)
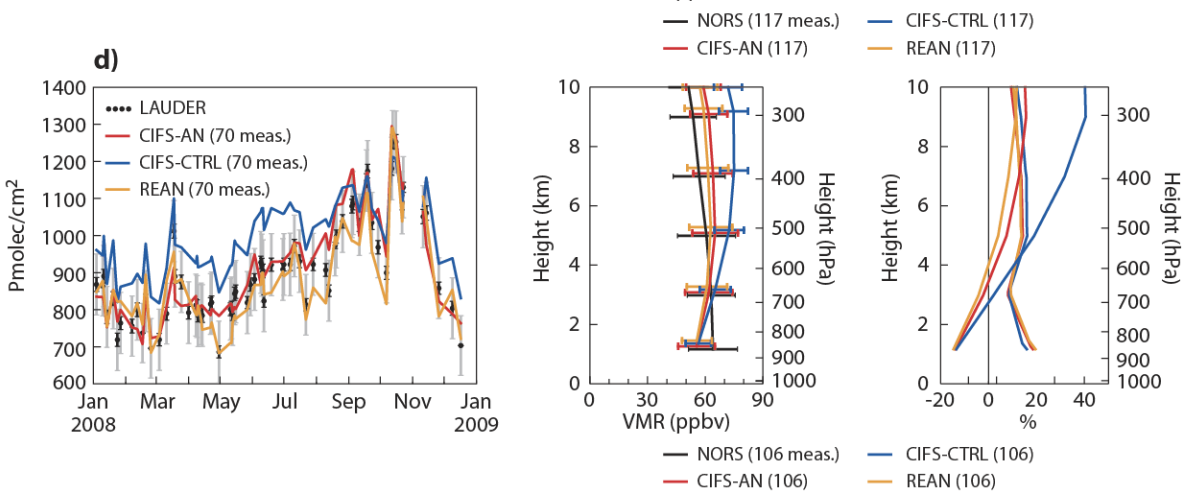

Figure 6. Time series of daily mean tropospheric CO columns (surface to $10 \mathrm{~km}$ ) in $10^{15}$ molecules $\mathrm{cm}^{-2}$ (left), annual mean CO volume mixing ratio profiles in ppbv (middle) and annual mean bias (model minus observation) profiles in \% (right, with dashed lines for spread) for the year 2008 for four NDACC stations: (a) Eureka, (b) Jungfraujoch, (c) Izaña and (d) Lauder. CIFS-AN is shown in red, CIFS-CTRL in blue and REAN in orange.

technique. Between June and October, when the model performs better, the differences between CIFS-AN and CIFSCTRL are small. Compared to REAN, which was created with an earlier version of the MACC system, CIFS-AN has an improved fit to the MOZAIC data in the LT throughout the year, with particular improvements during winter and spring.
This can partly be attributed to differences in the traffic emissions used in the runs. Stein et al. (2014) showed that the increased anthropogenic traffic emissions used in CIFS-AN had a large and positive effect on modelled NH CO concentrations. However, even when using the same anthropogenic emissions (as done in Flemming et al., 2015, their Fig. 8) 
the MOZART-CTM, which was coupled to IFS in REAN, has lower CO values at Frankfurt than a C-IFS (CB05) stand alone run. Hence differences between the MOZART and CIFS (CB05) physics and chemistry (e.g. different $\mathrm{OH}$ distributions and different parameterizations of dry deposition) also contribute. REAN agrees better with the MOZAIC data in the MT during summer which is likely to be due to the assimilation of additional IASI TCCO data in REAN.

At Windhoek all experiments underestimate the September/October maximum due to biomass burning in the LT and MT, but the assimilation of TCCO data leads to increased $\mathrm{CO}$ values in CIFS-AN and REAN and therefore smaller negative biases than CIFS-CTRL which underestimates the peak by $40-50 \mathrm{ppb}$, possibly due to an underestimation in the GFAS CO emissions. At other times of the year the impact of the assimilation in the LT and MT is smaller, and CIFS-AN has slightly lower CO values in the LT and MT than CIFSCTRL, which improves the fit to the MOZAIC data during some months and degrades it during others. The largest impact of the assimilation from January to September can be seen in the UT where CIFS-AN is about $10 \mathrm{ppb}$ lower than CIFS-CTRL. This is in agreement with the zonal mean differences seen in Fig. 4. Here, the fit to the MOZAIC data is degraded in CIFS-AN from January to April, but improved during the summer. CIFS-AN and REAN are of similar quality at Windhoek. REAN has a better fit to the MOZAIC data during in the LT and MRT during the biomass-burning season, but a larger negative bias than CIFS-AN in the UT.

$\mathrm{CO}$ from the C-IFS experiments is further validated against NDACC FTIR data for time series of tropospheric $\mathrm{CO}$ columns (from the surface to $10 \mathrm{~km}$ ), as well as annually averaged $\mathrm{CO}$ and bias profiles (Fig. 6). All experiments underestimate the tropospheric $\mathrm{CO}$ columns at the northern FTIR stations with annual mean biases at Eureka of $-6.0,-7.3,-16.9 \%$ and at Jungfraujoch of $-3.5,-3.5$ and $-3.0 \%$ for CIFS-AN, CIFS-CTRL and REAN, respectively. At Eureka, the largest differences between CIFS-AN and CIFS-CTRL are seen during winter. This agrees with the TCCO differences seen in Fig. 3. As already seen in Fig. 4, in the NH the assimilation of MOPITT TCCO leads to increased $\mathrm{CO}$ values in the mid and lower troposphere and to reduced $\mathrm{CO}$ values in the upper troposphere. This improves the fit to the FTIR data in CIFS-AN at Jungfraujoch and at Eureka in the lower and mid-troposphere, but leads to a worse fit than CIFS-CTRL in the upper troposphere at Eureka. REAN has a larger negative bias at Eureka after April. In Inness et al. (2013) and MACC Reanalysis validation reports (available from www.copernicus-atmosphere.eu) it was noted that the assimilation of IASI TCCO retrievals that started in REAN in April 2008 led to lower surface CO values in the polar regions. This was the result of differences between the assimilated MOPITT and IASI CO data. IASI data are lower than MOPITT over land and in the SH, with particularly large differences at high northern latitudes during winter (George et al., 2015). While the assimilation of
IASI CO improved the fit to surface observations over the Antarctic it led to larger negative biases at Arctic stations (see also GAW (Global Atmosphere Watch) evaluation below).

At Izaña all experiments overestimate CO below 500$600 \mathrm{hPa}$, and underestimate it above, with the largest biases in REAN. The differences between CIFS-AN and CIFSCTRL are small, which can also be seen in the annual mean tropospheric column biases of $-6.6 \%$ for CISF-AN and $-7.5 \%$ for CIFS-CTRL. At the SH station of Lauder all models underestimate $\mathrm{CO}$ below $700 \mathrm{hPa}$ and overestimate it above, with the largest positive bias in CIFS-CTRL and lowest in REAN. This large bias in CIFS-CTRL can also be seen in the Lauder FTIR time series of tropospheric CO. Figure 6 illustrates that the large reduction in upper tropospheric $\mathrm{CO}$ values due to the assimilation of MOPITT TCCO (seen in Fig. 4) leads to an improved fit with the FTIR data in this region.

Figure 7 shows an evaluation of monthly mean surface CO volume mixing ratios from the experiments against a selection of GAW stations. As already seen in the difference plots in Fig. 4 and the MOZAIC LT comparison in Fig. 5 the differences between CIFS-AN and CIFS-CTRL in the NH are largest during the winter season, when the $\mathrm{CO}$ lifetime is longest and the assimilation of MOPITT TCCO leads to increased surface $\mathrm{CO}$ values. The seasonal cycle is very well captured by CIFS-AN at Alert with a negligible annual mean bias, while CIFS-CTRL has a bias of -7 parts per billion volume (ppbv). At Mace Head there is again good agreement of CIFS-AN with the observations with a mean bias of 4 pbbv, compared to -6 ppbv in CIFS-CTRL. At both stations REAN has a larger negative bias $(-30$ and $-8 \mathrm{ppbv}$, respectively). This is in agreement with the large negative bias of REAN relative to FTIR data at Eureka (Fig. 6) and due to the assimilation of IASI TCCO retrievals that started in REAN in April 2008 and led to lower surface CO values in the polar regions. At Key Biscayne, all three experiments agree well with the observations, and REAN has the smallest annual mean bias. At Ascension Island the experiments capture well the change from low CO surface concentrations between January to June, to higher values from August onwards, which are related to transport of $\mathrm{CO}$ rich air from the African biomass-burning areas. REAN overestimates CO during the second half of the year and has the largest annual mean bias ( $7 \mathrm{ppbv})$. $\mathrm{CO}$ values are lower in CIFS-AN than in CIFS-CTRL ( -3 and 2 ppbv mean bias, respectively), but mainly within the SD of the observations. The lower values in CIFS-AN than in CIFS-CTRL between January and July agree with what is seen in comparison with MOZAIC data at Windhoek in the LT (Fig. 5). At Samoa, all three experiments capture the low $\mathrm{CO}$ background values over the $\mathrm{Pa}$ cific, but CIFS-CTRL overestimates CO more throughout the year (mean bias of 4 ppbv), while CIFS-AN underestimates it in the first half of the year and overestimates it in the second half, leading to an annual mean bias of $0 \mathrm{ppbv}$. At South 

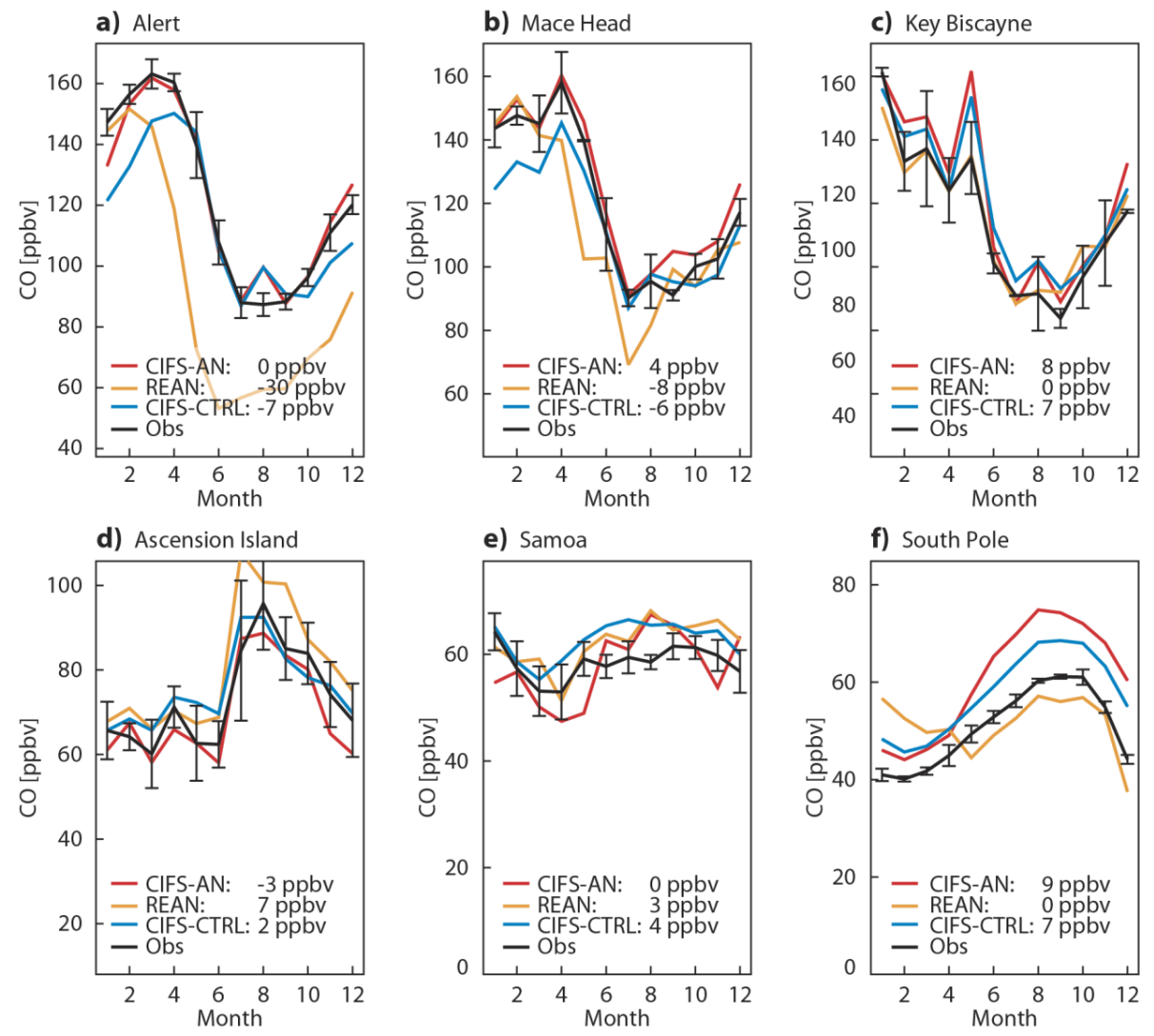

Figure 7. Time series for 2008 of monthly mean surface CO volume mixing ratios (ppbv) at a selection of GAW stations (black), CIFS-AN (red), CIFS-CTRL (blue) and REAN (orange): (a) Alert $\left(82.3^{\circ} \mathrm{N}, 62.2^{\circ} \mathrm{W}\right)$, (b) Mace Head $\left(53.2^{\circ} \mathrm{N}, 9.5^{\circ} \mathrm{W}\right)$, (c) Key Biscayne $\left(25.4^{\circ} \mathrm{N}\right.$, $\left.80.9^{\circ} \mathrm{W}\right)$, (d) Ascension Island $\left(7.6^{\circ} \mathrm{S}, 14.3^{\circ} \mathrm{W}\right)$, (e) Samoa $\left(13.5^{\circ} \mathrm{S}, 171.5^{\circ} \mathrm{W}\right)$ and (f) South Pole $\left(90^{\circ} \mathrm{S}, 0^{\circ} \mathrm{E}\right)$. Error bars $($ only shown for the observations) denote the monthly mean variability in the observations. Also given is the annual mean bias of the three experiments.

Pole CIFS-AN and CIFS-CTRL overestimate the surface CO values with larger biases in CIFS-AN than in CIFS-CTRL ( 9 and 7 ppbv, respectively). In REAN, the agreement with the observations is noticeably improved after the start of the assimilation of IASI CO in April 2008.

The comparisons with independent validation data have shown that by assimilating total column $\mathrm{CO}$ retrievals several aspects of the 3-dimensional CO field can be improved compared to a control run without data assimilation. In the $\mathrm{NH}$, the largest impact is an increase of $\mathrm{CO}$ in the lower troposphere and at the surface during $\mathrm{NH}$ winter and spring. In the tropics $\mathrm{CO}$ is decreased throughout the troposphere, and in the SH CO is decreased in the mid- to upper troposphere. It may be possible to further improve the vertical structure of the $\mathrm{CO}$ field by assimilating retrieved $\mathrm{CO}$ profiles from MOPITT, IASI or the Thermal Emission Spectrometer (TES) instead of the total column products. The C-IFS (CB05) model has problems capturing the summer-time $\mathrm{CO}$ maximum due to biomass burning at Windhoek in the $\mathrm{SH}$, and the assimilation can only partly correct this. Here it might be beneficial to have improved biomass-burning emissions that use a more realistic injection height. Also C-IFS (CB05) over- estimates $\mathrm{CO}$ production originating mostly from isoprene emissions and chemistry over Indonesia and Central Africa (see Fig. S1).

\subsection{Ozone}

\subsubsection{Impact of the $\mathrm{O}_{3}$ assimilation}

The histograms of SCIAMACHY and OMI analysis departures in Fig. 8 illustrate that CIFS-CTRL has large TCO3 biases and that the assimilation of ozone retrievals is essential to improve the fit with the OMI and SCIAMACHY data. The signs of the biases are consistent for SCIAMACHY and OMI. TCO3 is dominated by ozone in the stratosphere and having a simple photochemical parameterization of the stratospheric ozone chemistry (see Sect. 2.1) is a weakness of C-IFS (CB05). CIFS-CTRL overestimates TCO3 in the $\mathrm{NH}$ (obs-an $<0$ ) with a mean annual bias of 22 Dobson units (DU) relative to SCIAMACHY and 14 DU relative to OMI. It underestimates $\mathrm{TCO} 3$ in the tropics by $-18 \mathrm{DU}$ relative to SCIAMACHY and -28 DU relative to OMI in the annual mean, and in the SH by -7 DU relative to SCIAMACHY and -19 DU relative to OMI. Figure 9 shows that, as expected, 

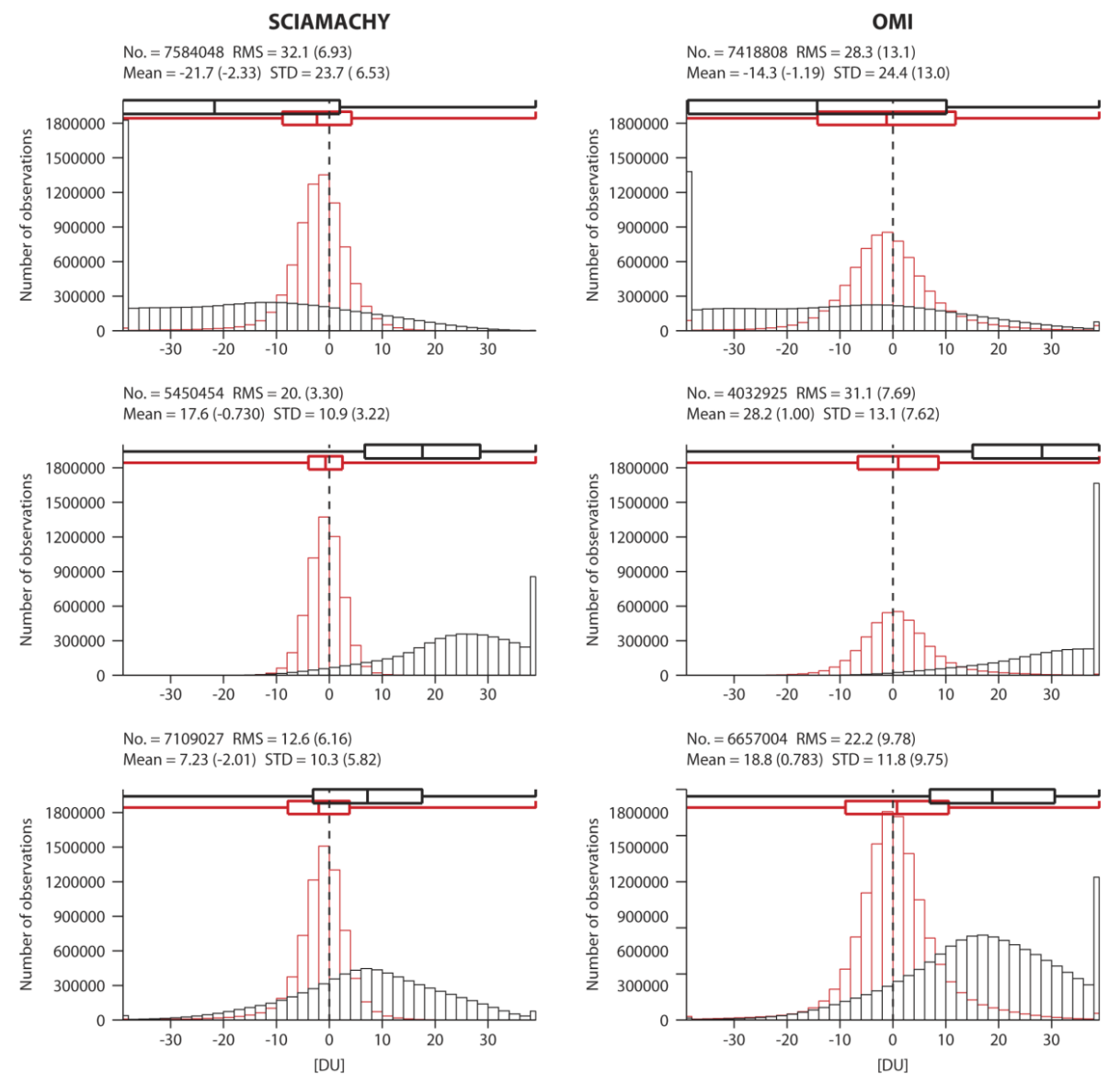

Figure 8. Histograms of SCIAMACHY (left) and OMI (right) TCO3 analysis departures in DU for CIFS-AN (red) and CIFS-CTRL (black) for 2008 averaged over the $\mathrm{NH}\left(90-20^{\circ} \mathrm{N}\right.$, top), the tropics $\left(20^{\circ} \mathrm{N}-20^{\circ} \mathrm{S}\right.$, middle) and the $\mathrm{SH}\left(20-90^{\circ} \mathrm{S}\right.$, bottom) for all good data. Also shown above the panels are the number of observations that make up the average, as well as the mean, RMS and SD of the departures with values for REAN in brackets.

the fit to MLS and MIPAS profile data is also strongly improved and that the assimilation of ozone retrievals leads to much smaller biases and SDs of the departures in the vertical in CIFS-AN.

Figure 10 shows the zonal mean TCO3 differences of the experiments and the assimilated OMI observations, and illustrates how the assimilation leads to lower $\mathrm{O}_{3}$ values in the extratropics and higher values in the tropics and to a much improved fit with the OMI data compared to CIFS-CTRL. The seasonal mean vertical differences between CIFS-AN and CIFS-CTRL are given in Fig. 11 and show large differences between the two experiments. Seasonal mean OMI analysis increments and a time series of the zonal mean analysis increments are shown in the supplement (Figs. S4 and S5). Like for CO, the analysis increments are small (mainly less than 1\%) after an initial adjustment in January 2008.

\subsubsection{Stratospheric and total column ozone evaluation}

Figure 12 shows time series of the monthly mean TCO3 from the experiments and KNMI's multi sensor reanalysis
(MSR) for the year 2008 for the NH, tropics and SH. Note that the MSR also used SBUV/2, SCIAMACHY and OMI data which are assimilated in CIFS-AN. The figure confirms that the assimilation of ozone retrievals leads to a greatly improved TCO3 in CIFS-AN compared to CIFS-CTRL, which overestimates TCO3 with respect to the MSR data in the $\mathrm{NH}$ by up to $40 \mathrm{DU}$, and underestimates it in the tropics (up to $-50 \mathrm{DU}$ ) and to a smaller extent in the SH (up to $-30 \mathrm{DU}$, but good agreement of the columns from April to July). Despite the simple stratospheric ozone parameterization (see Sect. 2.1) used in C-IFS (CB05), CIFS-AN shows better agreement with the MSR data than REAN, illustrating the strong constraints of the assimilation of ozone data for providing good quality total column fields.

Figure 13 shows time series of monthly mean stratospheric $\mathrm{O}_{3}$ biases between the experiments and ACE-FTS and MIPAS data for stratospheric layer between $30-70 \mathrm{hPa}$ for the Antarctic, tropics and Arctic. Plots for the layers 10-30 and $70-150 \mathrm{hPa}$ are shown in Figs. S5 and S6 in the Supplement. The figures show that in all three altitude ranges the 
a)

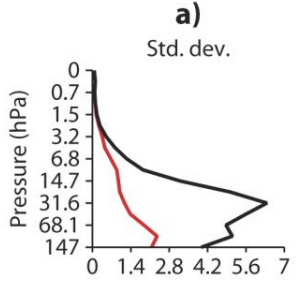

Std. dev.

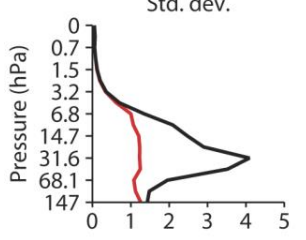

Std. dev.

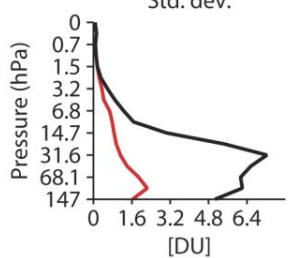

b)
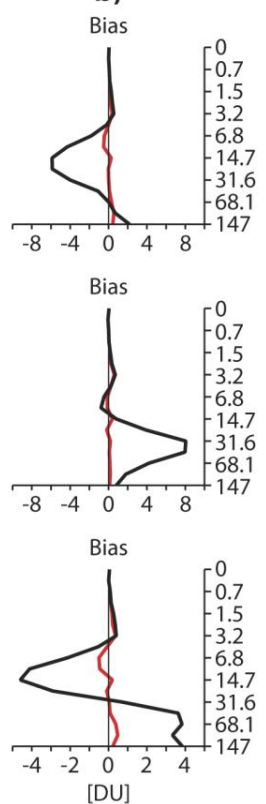

c)

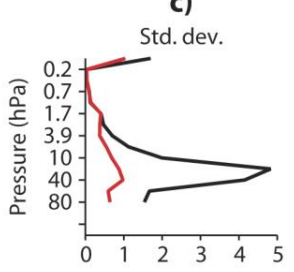

Std. dev.

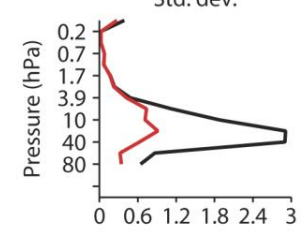

Std. dev.

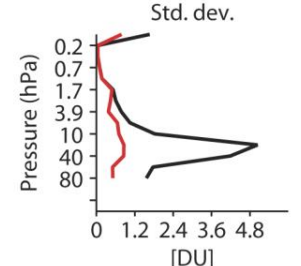

d)
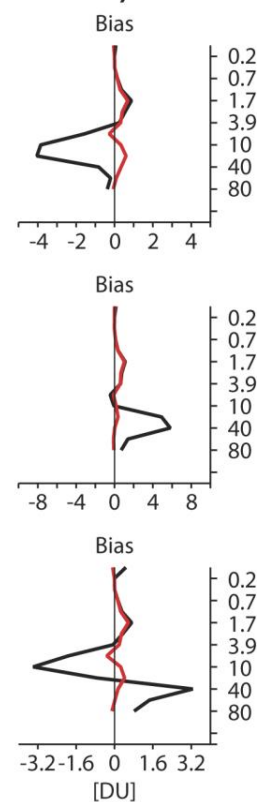

Figure 9. (a) Annual mean SD of MLS analysis departures and (b) MLS analysis departures, as well as (c) SD of MIPAS analysis departures and (d) MIPAS analysis departures in DU from CIFS-AN (red) and CIFS-CTRL (black) averaged over the $\mathrm{NH}\left(90-20^{\circ} \mathrm{N}\right.$, top), the tropics $\left(20^{\circ} \mathrm{N}-20^{\circ} \mathrm{S}\right.$, middle) and the $\mathrm{SH}\left(20-90^{\circ} \mathrm{S}\right.$, bottom) for all good data in 2008.
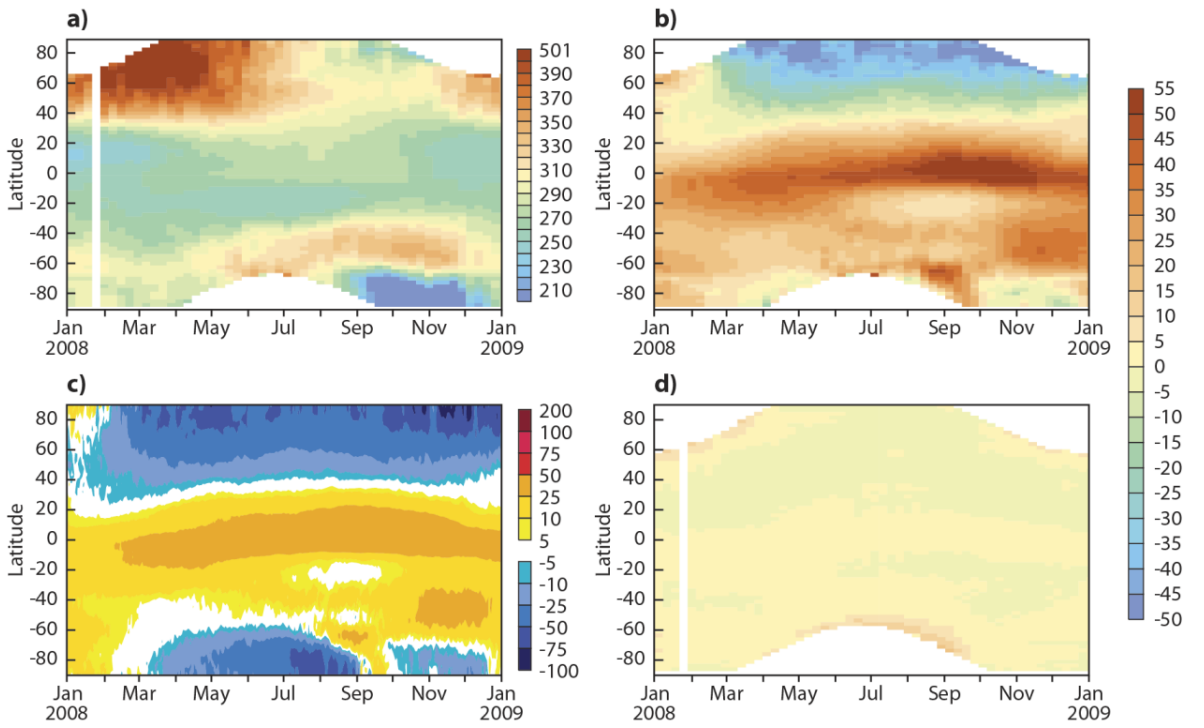

Figure 10. Time series of (a) zonal mean TCO3 in DU from OMI, zonal mean TCO3 analysis departures in \% of (b) CIFS-CTRL and (d) CIFS-AN, and (c) of the zonal mean relative difference of CIFS-AN minus CIFS-CTRL. In (a) red indicates higher values of the field, blue lower values. In (b)-(d) red indicates positive values, blue negative values.

assimilation leads to an improved fit to the ACE and MIPAS data and that biases and SDs are much reduced in CIFSAN compared to CIFS-CTRL. The biases of CIFS-AN with respect to ACE-FTS are never larger than $15 \%$. The assimilation corrects especially well the large biases modelled by CIFS-CTRL above the Antarctic. Lefever et al. (2015) showed that this success is primarily due to the assimilation of profile data, such as MLS or MIPAS. The differences between CIFS-AN and REAN are small in all areas and altitude ranges. 

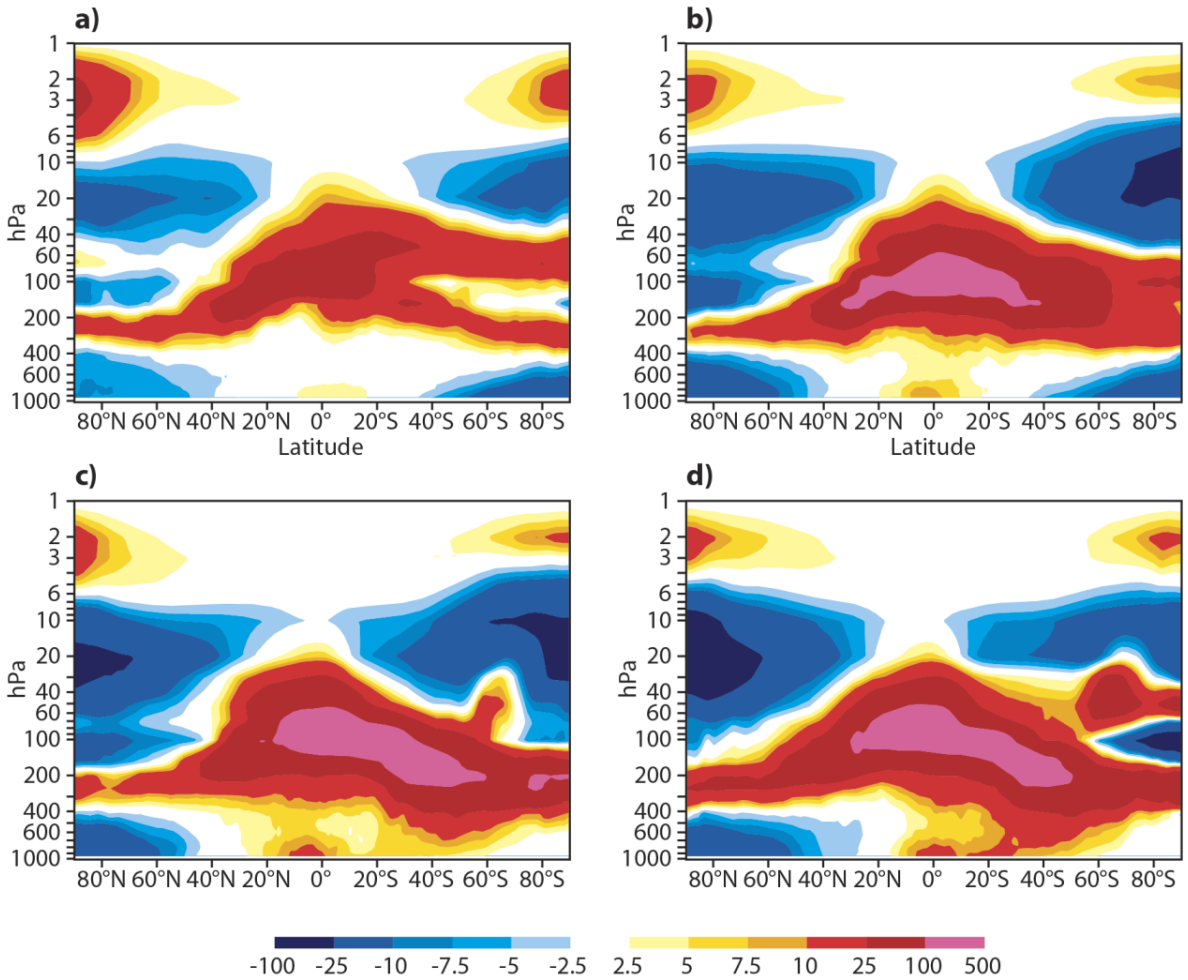

Figure 11. Cross sections of seasonal mean zonal mean relative $\mathrm{O}_{3}$ differences in \% between CIFS-AN minus CIFS-CTRL in ppb for (a) JF, (b) MAM, (c) JJA and (d) SON 2008. Red indicates positive values, blue negative values.
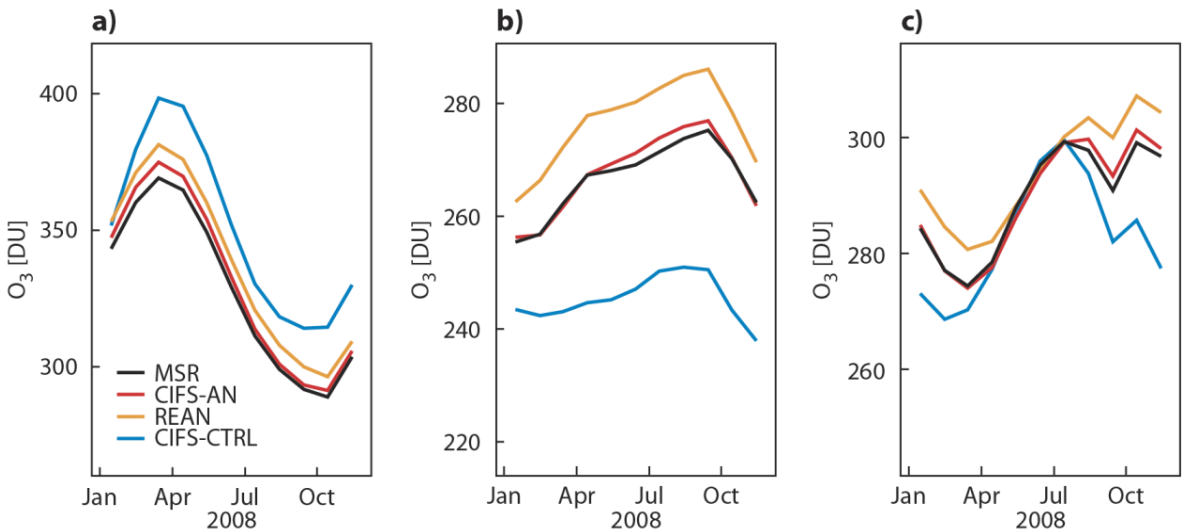

Figure 12. Time series for 2008 of the mean TCO3 of CIFS-AN (red), CIFS-CTRL (blue), REAN (orange) and the multi sensor reanalysis (black) in DU averaged over the (a) $\mathrm{NH}$ extratropics $\left(30-90^{\circ} \mathrm{N}\right)$, (b) tropics $\left(30^{\circ} \mathrm{S}-30^{\circ} \mathrm{N}\right)$ and (c) $\mathrm{SH}$ extratropics $\left(90-30^{\circ} \mathrm{S}\right)$.

\subsubsection{Tropospheric and surface ozone evaluation}

Time series of monthly mean tropospheric $\mathrm{O}_{3}$ from ozone sondes and the experiments averaged over the LT, MT and UT are shown in Fig. 14 for Europe, North America and eastern Asia and in Fig. 15 for the tropics, Arctic and Antarctic. It should be stressed that only ozone total column and stratospheric profile ozone data (see Table 1) are assimilated in CIFS-AN and REAN and that the impact on the troposphere comes as the residual of combining those data sets. The sea- sonal cycles are well reproduced in all experiments in most areas, but there are some biases compared to the sonde data, particularly in the LT and for CIFS-CTRL also in the UT. In all six areas, $\mathrm{O}_{3}$ in the UT is improved in CIFS-AN compared to CIFS-CTRL as the impact of the assimilation of stratospheric and total column ozone data corrects model biases here. CIFS-AN and REAN are generally very close in the UT, except in the tropics where CIFS-AN fits the observations better. 

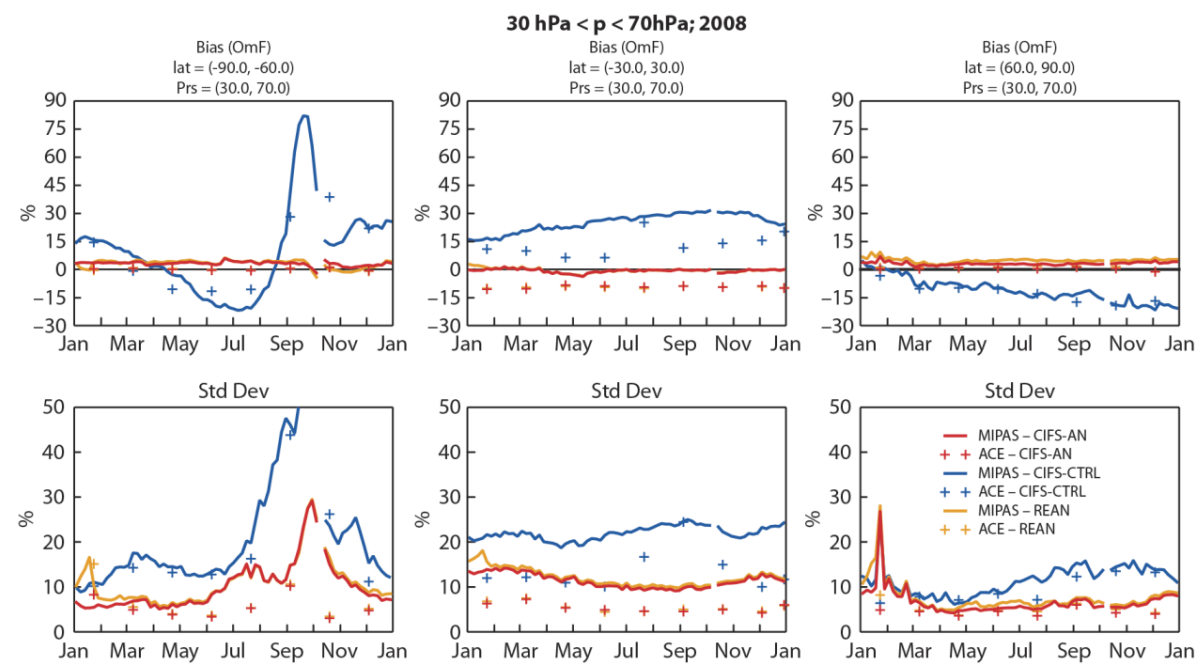

Figure 13. Time series for 2008 of monthly mean differences (top) and SD (bottom) in \% of the experiments, ACE data (plus symbols) and MIPAS data (solid) averaged over the pressure range between 30 and $70 \mathrm{hPa}$, for the Antarctic $\left(90\right.$ to $60^{\circ} \mathrm{S}$, left), the tropics $\left(30^{\circ} \mathrm{S}\right.$ to $30^{\circ} \mathrm{N}$, centre) and the Arctic (60 to $90^{\circ} \mathrm{N}$, right). CIFS-AN is shown in red, CIFS-CTRL in blue, and REAN in orange.

a)
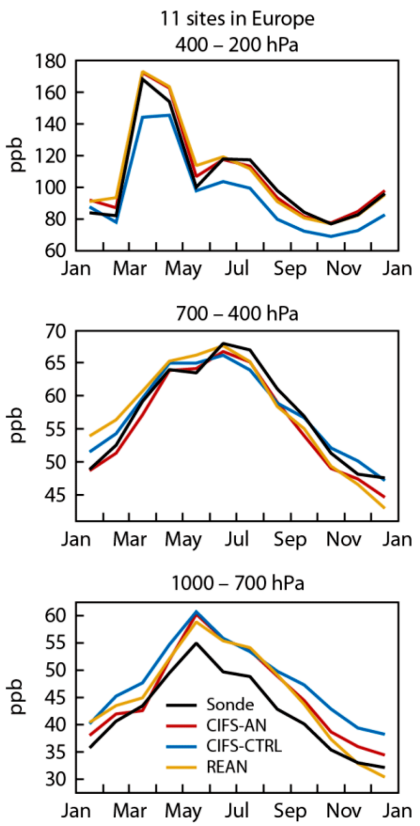

b)

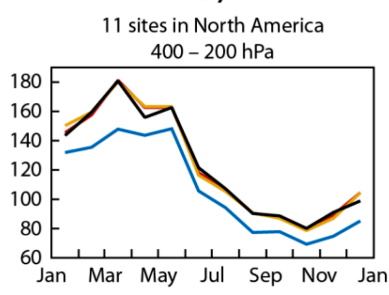

$700-400 \mathrm{hPa}$
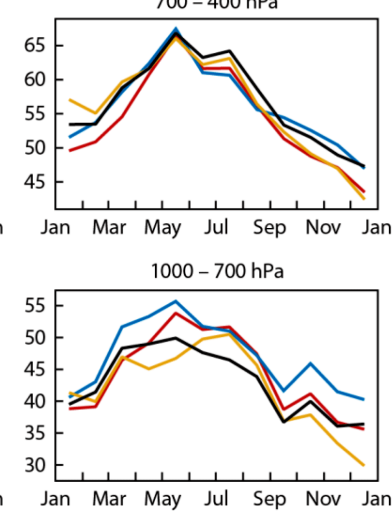

c)

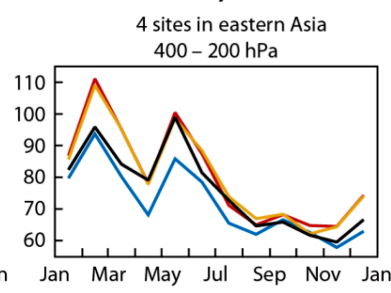

$700-400 \mathrm{hPa}$
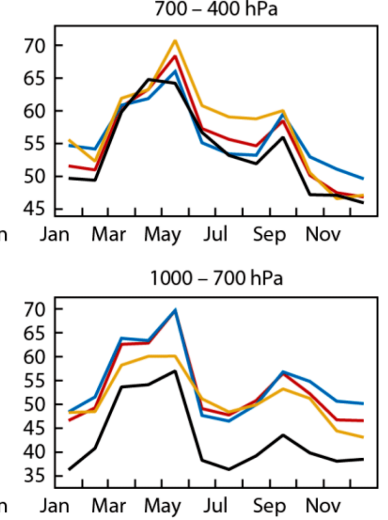

Figure 14. Time series of monthly mean tropospheric $\mathrm{O}_{3}$ in ppb over (a) Europe (11 stations), (b) North America (11 stations) and (c) eastern Asia (4 stations) averaged in the pressure bands $1000-700 \mathrm{hPa}$ (bottom), $700-400 \mathrm{hPa}$ (middle) and 400-200 hPa (top) from ozonesondes (black), CIFS-AN (red), CIFS-CTRL (blue) and REAN (orange) in 2008.

Note that the tropopause is higher in the tropics and that $\mathrm{O}_{3}$ in the UT is more influenced by the modelling of tropospheric processes, and hence differences in the chemistry schemes, than at higher latitudes where downward $\mathrm{O}_{3}$ transport from the stratosphere is larger (e.g. Škerlak et al., 2014). In the MT and LT, the differences between CIFS-AN and CIFS-CTRL are smaller than in the UT, but there are larger differences between CIFS-AN and REAN here. This indi- cates that the impact of the assimilated data gets smaller and the differences between the chemistry schemes become more important lower in the troposphere.

In the $\mathrm{LT}$ the spring and summer time $\mathrm{O}_{3}$ maxima over Europe and North America are overestimated by CIFS-CTRL and this overestimation is not corrected in CIFS-AN. However, during winter and spring the assimilation has some impact on the LT, and CIFS-AN agrees better with the 
a)
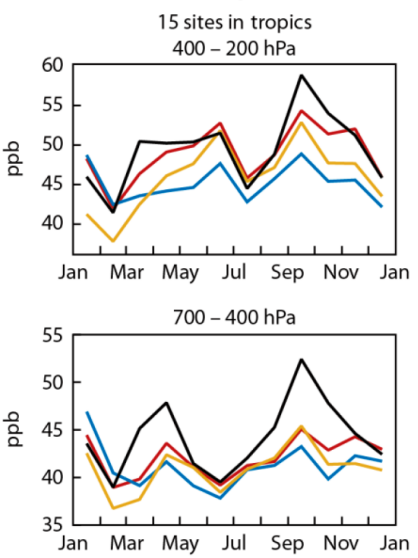

$1000-700 \mathrm{hPa}$

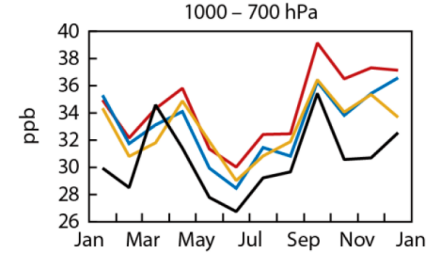

b)

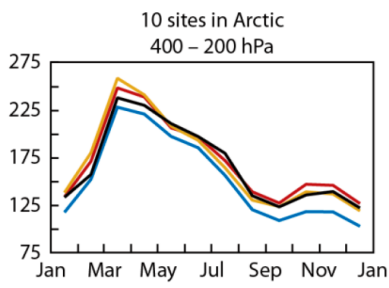

$700-400 \mathrm{hPa}$

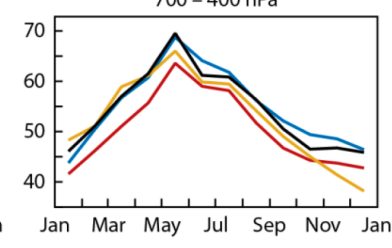

$1000-700 \mathrm{hPa}$

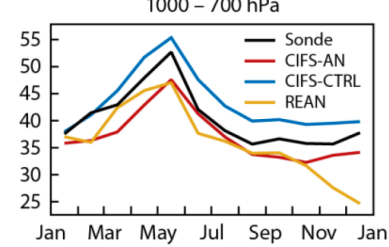

c)

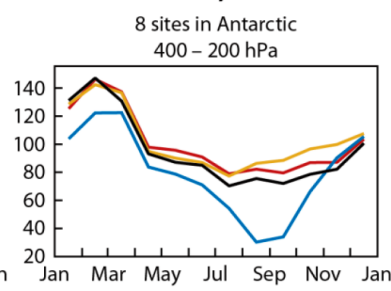

$700-400 \mathrm{hPa}$

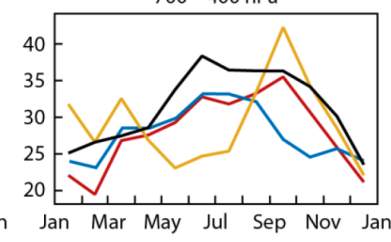

$1000-700 \mathrm{hPa}$

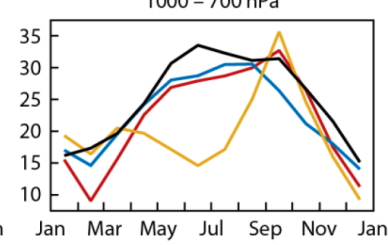

Figure 15. Time series of monthly mean tropospheric $\mathrm{O}_{3}$ in ppb over (a) tropics (15 stations), (b) Arctic (10 stations) and (c) Antarctic (8 stations) averaged in the pressure bands $1000-700 \mathrm{hPa}$ (bottom), 700-400 hPa (middle) and 400-200 hPa (top) from ozonesondes (black), CIFS-AN (red), CIFS-CTRL (blue) and REAN (orange) in 2008.

observations over Europe and North America than CIFSCTRL. REAN also overestimates $\mathrm{O}_{3}$ in the LT over Europe during the summer, but less so over North America. In the MT, CIFS-AN has the best fit to the observations over Europe, but a worse fit than CIFS-CTRL over North America.

Over eastern Asia (the average of Hong Kong and three Japanese stations, see Table $\mathrm{S} 5$ in the Supplement) $\mathrm{O}_{3}$ in the LT is overestimated throughout the year with little differences between CIFS-CTRL and CIFS-AN, apart for smaller biases in CIFS-AN from October to December. REAN also overestimates $\mathrm{O}_{3}$ in the LT but has the best fit to the observations from March to May. In the MT, the assimilation leads to an improved fit with the sondes over eastern Asia during winter. At other times of the year CIFS-AN and CIFS-CTRL are similar and agree better with the sondes than REAN.

The $\mathrm{O}_{3}$ time series in the tropics (Fig. 15) are characterized by two ozone maxima due to biomass burning during the dry seasons in South America (Arpil/May) and Indonesia (September). CIFS-CTRL can not reproduce these peaks well in the MT and UT and the assimilation improves the fit to the sondes, particularly in the UT and to a smaller extent in the MT. In the LT, CIFS-AN has a larger positive bias than CIFS-CTRL. CIFS-CTRL also had problems capturing the high $\mathrm{CO}$ values see at Windhoek during the biomass-burning season (see Fig. 5) and the lower $\mathrm{O}_{3}$ values might be a result of an underestimation of the $\mathrm{O}_{3}$ production because of an underestimation of the precursors.
In the Arctic, the seasonal cycle with maximum in late spring is well reproduced in all experiments, but there are some biases. In the LT, CIFS-CTRL overestimates the observed $\mathrm{O}_{3}$, while CIFS-AN and REAN underestimate $\mathrm{O}_{3}$. In the MT, CIFS-CTRL has the best agreement with the observations, while CIFS-AN has a negative bias. CIFS-AN and REAN agree best with the observations in the UT.

In the Antarctic, CIFS-AN and CIFS-CTRL underestimate $\mathrm{O}_{3}$ in the LT and MT but roughly capture the seasonal cycle, while REAN has problems reproducing the ozone distribution in the LT and MT. This is due to vertical correlation in the background error statistics used in REAN. REAN did not perform well in the polar lower troposphere because large biases in stratospheric ozone in the underlying model in the polar regions (see Inness et al., 2013) required large corrections by the analysis. The background errors used in REAN had vertical correlations between the lower troposphere and the upper troposphere and stratosphere which led to poor vertical tropospheric $\mathrm{O}_{3}$ profiles over the poles as the assimilation of stratospheric data led to (unwanted) changes near the surface. The ozone background errors were modified for CIFS-AN (see Sect. 2.2) to remove these correlations, and CIFS-AN scores better here.

In all runs, $\mathrm{NO}_{2}$ is underestimated over areas of anthropogenic pollution (see Figs. 22 and 23 below), which is a well known problem in the MACC system (Inness et al., 2013; Flemming et al., 2015). The model is not able to resolve local-scale high levels of nitrogen oxides $\left(\mathrm{NO}_{x}\right)$ observed in 

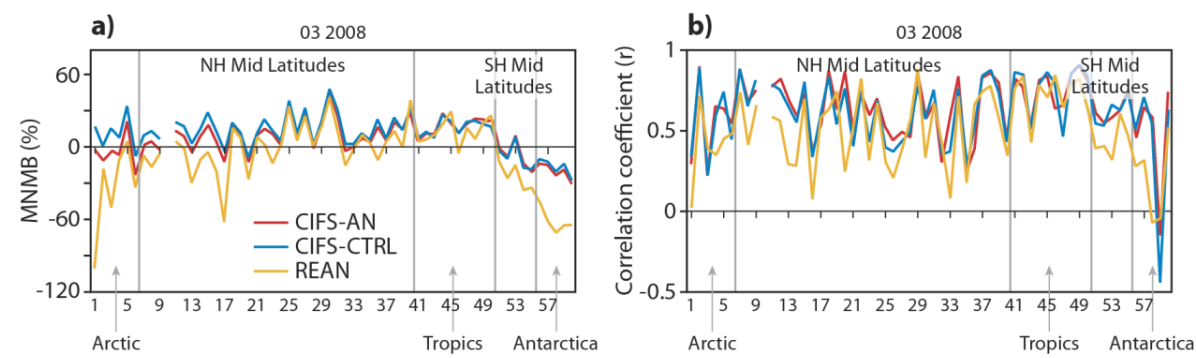

Figure 16. (a) Modified normalized mean biases (MNMBs) in \% and (b) correlation coefficients (from daily mean values) for GAW stations during the whole of 2008. The stations are ordered by latitude from north to south. For station numbers see Table S4. CIFS-AN is shown in red, CIFS-CTRL in blue and REAN in orange.

polluted areas because of its coarse resolution, but distributes this over the whole grid box. Therefore, with more diluted $\mathrm{NO}_{2}$ in high pollution regions, the model is shifted towards a regime of $\mathrm{O}_{3}$ production $\left(\mathrm{NO}_{x}\right.$-limited) rather than $\mathrm{O}_{3}$ loss, which might contribute to the positive $\mathrm{O}_{3}$ bias seen in the $\mathrm{LT}$ in all areas except Antarctica. Such high bias of $\mathrm{O}_{3}$ in the LT at northern mid-latitudes is a general problem of global-scale CTMs, e.g. Young et al. (2013).

Figure 16 shows modified normalized mean biases (MNMBs) and correlation coefficients (see supplement for definitions) from the three experiments against GAW stations (see Table S4) for 2008. CIFS-CTRL has a positive bias at the surface, except over Antarctica, as already seen in Figs. 14 and 15 . The assimilation generally leads to lower surface $\mathrm{O}_{3}$ and reduces the MNMB in the Arctic and NH Midlatitudes, but the differences are small. The correlations are not changed noticeably in CIFS-AN. REAN has larger negative biases than the C-IFS runs in the polar regions and in midlatitudes. The differences between REAN and CIFS-AN are particularly large in the polar regions due to the background error formulation used in REAN as already discussed above.

In summary, comparing the experiments with tropospheric ozone observations shows that there is some positive impact on the troposphere, even though only $\mathrm{O}_{3}$ total column and stratospheric profile data (see Table 1) were assimilated. The improvement is particularly large in the UT, but smaller in the MT and LT where characteristics of the underlying chemistry scheme become more important. There are, however, some pronounced improvements in CIFS-AN compared to REAN in the LT and surface ozone, which are at least partly the result of modifications to the ozone background error correlations used in CIFS-AN.

\subsection{Nitrogen dioxide}

\subsubsection{Impact of the $\mathrm{NO}_{2}$ assimilation}

The histograms of OMI analysis and first-guess departures in Fig. 17 illustrate that the reductions of bias, RMS and $\mathrm{SD}$ due to the assimilation of OMI tropospheric $\mathrm{NO}_{2}$ column (TRCNO2) retrievals are much smaller than the impact seen from the assimilation of $\mathrm{CO}$ and $\mathrm{O}_{3}$ data (Figs. 2 and 8) and the distributions remain skewed towards positive departures (observations $>$ analysis). This does not mean that the assimilation of $\mathrm{NO}_{2}$ has no impact in the model. Figure 18 shows the seasonal mean $\mathrm{NO}_{2}$ analysis column increments from CIFS-AN and illustrates that the $\mathrm{NO}_{2}$ increments are considerably larger ( $>20 \%$ over most land surfaces) than the average increments for $\mathrm{CO}$ and $\mathrm{O}_{3}$ (see Figs. $\mathrm{S} 1$ and $\mathrm{S} 3$ ). These large $\mathrm{NO}_{2}$ analysis increments can further be seen in the zonal mean time series (Fig. 19).

Figure 19 also illustrates that, unlike the TCCO and TCO3 increments, there is no initial adjustment followed by smaller analysis increments, but that the increments remain of similar magnitude throughout 2008. For $\mathrm{CO}$ and $\mathrm{O}_{3}$ the analysis is drawing to the assimilated data and the information is maintained and carried over into the next analysis cycles, because of the longer lifetimes of these species. The background field for a subsequent analysis cycle is therefore closer to the data, and the analysis increments get smaller with time. Because of the short lifetime of $\mathrm{NO}_{2}$, however, the information brought into the analysis by the $\mathrm{OMI} \mathrm{NO}_{2}$ data is quickly lost and not carried over into the next analysis cycle.

This is further illustrated in Fig. 20 which compares seasonal mean differences between the $\mathrm{NO}_{2}$ analysis fields from CIFS-AN and CIFS-CTRL and differences of $12 \mathrm{~h}$ forecasts started from these analyses. While there are large differences between the CIFS-AN and CIFS-CTRL $\mathrm{NO}_{2}$ analyses, these differences are almost entirely lost in the subsequent $12 \mathrm{~h}$ forecast. The largest remaining differences between the forecasts are seen in JF in the $\mathrm{NH}$ when the $\mathrm{NO}_{2}$ lifetime is longest. This means that with the $12 \mathrm{~h} 4 \mathrm{D}$-Var configuration used in CIFS-AN, most of the information brought into the analysis by OMI TRCNO2 is lost in the subsequent $12 \mathrm{~h}$ long trajectory. This is made worse by the fact that $\mathrm{OMI} \mathrm{NO} 2$ observations are only available during the day, when $\mathrm{NO}_{2}$ is photolysed by sunlight, and observations are only available for part of the globe during every analysis cycle.

As noted by Carmichael et al. (2008), Wang et al. (2008) and Silver et al. (2013) perturbations of the initial conditions can be brief for short lived species, as forcing from 


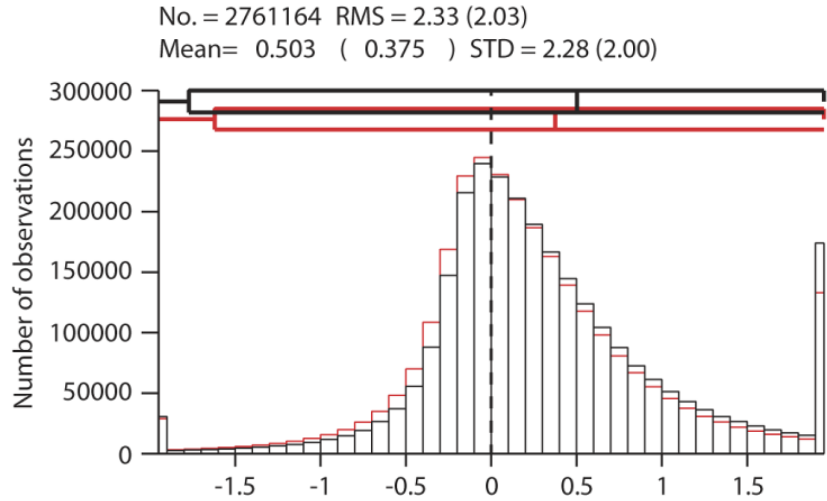

No. $=3693380$ RMS $=0.749(0.713)$

Mean $=0.376(0.345)$ STD $=0.648(0.624)$

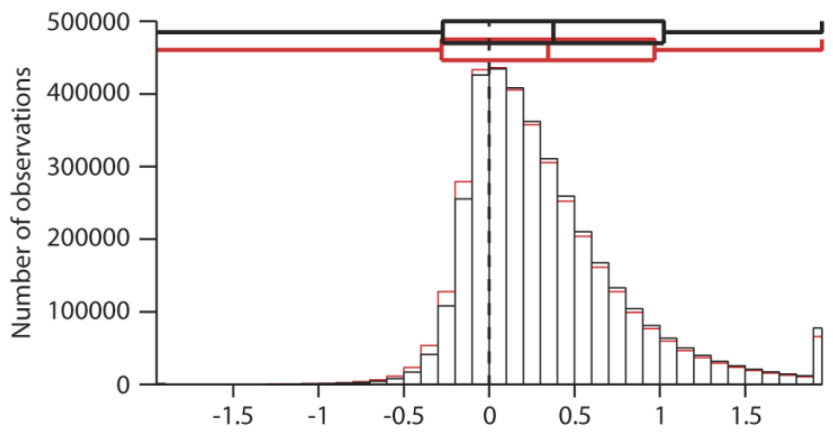

No. $=2478904$ RMS $=0.850(0.816)$

Mean $=0.393(0.362)$ STD $=0.754(0.731)$

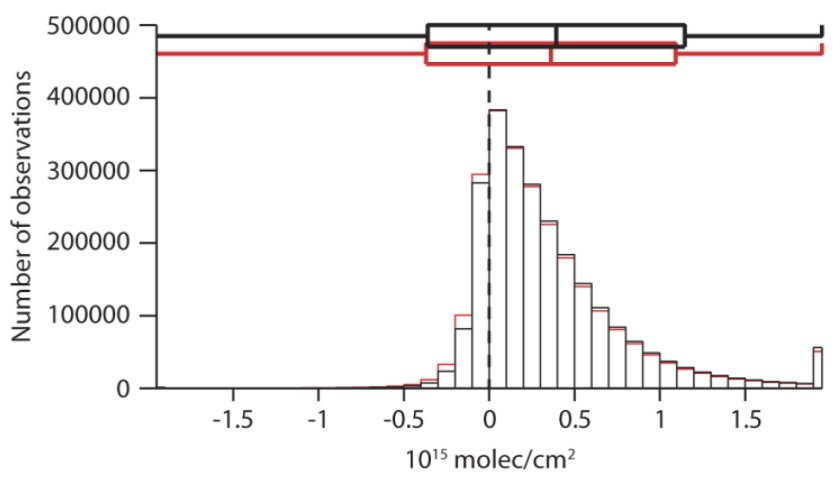

Figure 17. Histograms of OMI TRCNO2 analysis departures for CIFS-AN (red) and CIFS-CTRL (black) for 2008 averaged over the $\mathrm{NH}\left(90-20^{\circ} \mathrm{N}\right.$, top $)$, the tropics $\left(20^{\circ} \mathrm{N}-20^{\circ} \mathrm{S}\right.$, middle) and the $\mathrm{SH}$ (20-90 $\mathrm{S}$, bottom) for all good data in $10^{15}$ molecules $\mathrm{cm}^{-2}$. Also shown above the panels are the number of observations that make up the average, as well as the mean, RMS and SD of the departures with values for REAN in brackets.

sources and sinks such as chemistry and emissions will drive the fields back to chemical equilibrium. This limits the usefulness of data assimilation in adjusting the initial conditions for species such as $\mathrm{NO}_{2}$. Wang et al. (2008) found a small improvement in surface $\mathrm{NO}_{2}$ concentrations when they assimilated $\mathrm{OMI} \mathrm{NO} 2$ retrievals over Europe, and also some improvement in the next day forecast. They concluded that the impact might vary with season because of the shorter lifetime of $\mathrm{NO}_{2}$ during the summer. This agrees with our Fig. 20. Our study confirms that short lived species like $\mathrm{NO}_{2}$ would be more successfully corrected by adjusting the emissions instead of the initial conditions (e.g. Elbern et al., 2000; Miyazaki et al., 2012b). It is planned to include emissions in the control vector in the future so that they can be adjusted in addition to the initial conditions in the MACC system.

\subsubsection{Tropospheric $\mathrm{NO}_{2}$ evaluation}

The evaluation with GOME-2 TRCNO2 data in Fig. 21 confirms that, in absolute terms, the differences between CIFSAN and CIFS-CTRL are small. Figure 21 shows maps of annual mean TRCNO2 from GOME-2 and the three experiments. The experiments capture the global $\mathrm{NO}_{2}$ distribution seen by GOME-2 well with high values over areas of high anthropogenic, as well as boreal and tropical biomass-burning emissions. This illustrates that C-IFS (CB05) and the coupled MACC system that was used in REAN have a reasonable $\mathrm{NO}_{2}$ field despite the limited impact of the $\mathrm{NO}_{2}$ assimilation (Fig. 17). However, there are some noticeable differences between the modelling experiments and the GOME-2 retrievals. The experiments underestimate TRCNO2 over the regions of anthropogenic pollution in Europe, North America and eastern Asia and also the tropospheric background values over Africa, Eurasia and Australia. Furthermore, the models overestimate satellite values over India, the Persian Gulf and the Red Sea, and ship tracks (e.g. over the Indian Ocean) are more pronounced in the experiments than in the GOME- 2 columns. The ship plumes are highly concentrated just after release, and fast initial chemistry is not described in the course resolution model with instantaneous chemistry. On the other side, ship emission inventories are also very uncertain and may be too high (Vinken et al., 2014).

Comparison of the experiments against area averaged time series of monthly mean GOME-2 TRCNO2 shows that magnitude and seasonality of tropospheric $\mathrm{NO}_{2}$ columns (Fig. 22) over Europe and North America are rather well reproduced, indicating that emission patterns and $\mathrm{NO}_{x}$ photochemistry are reasonably represented here. However, all experiments tend to be lower than GOME-2 $\mathrm{NO}_{2}$ over Europe during the summer, but the differences might be within the error bars of the retrieval, which can have large uncertainties (e.g. van Noije et al., 2006). This low bias against satellite data was also seen for other regional models (Huijnen et al., 2010a). The simulations significantly underestimate the annual cycle of $\mathrm{NO}_{2}$ columns over eastern Asia, where the wintertime maximum is severely underestimated, while the summertime values agree better. Part of this might be due to an overestimation of TRCNO2 by the GOME-2 retrieval, which gives higher values here during winter than other retrieval algorithms (van Noije et al., 2006). Further reasons could be an underestimation of anthropogenic $\mathrm{NO}_{2}$ 
a)
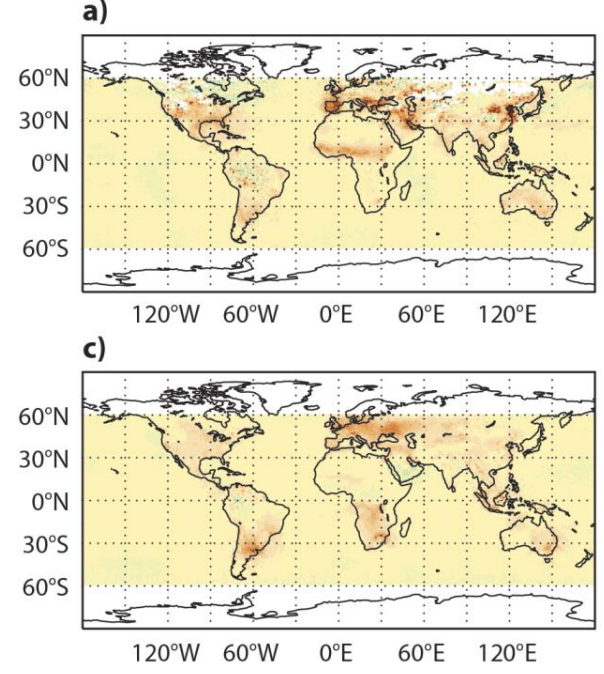

b)

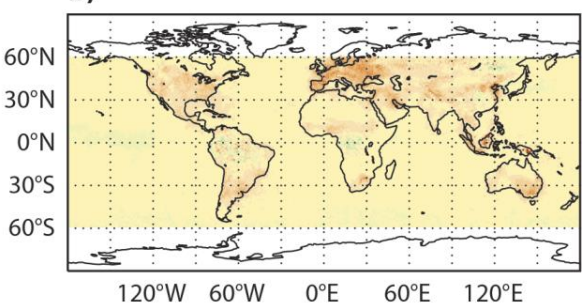

d)

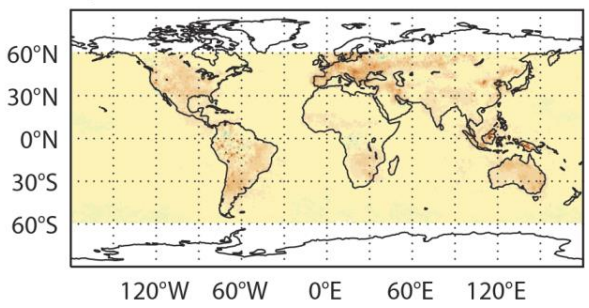

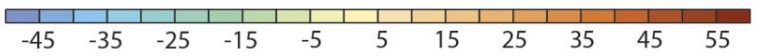

Figure 18. OMI TRCNO2 analysis increment (analysis minus forecast) in \% from CIFS-AN averaged over (a) JF, (b) MAM, (c) JJA and (d) SON 2008. Red indicates positive values, blue negative values.

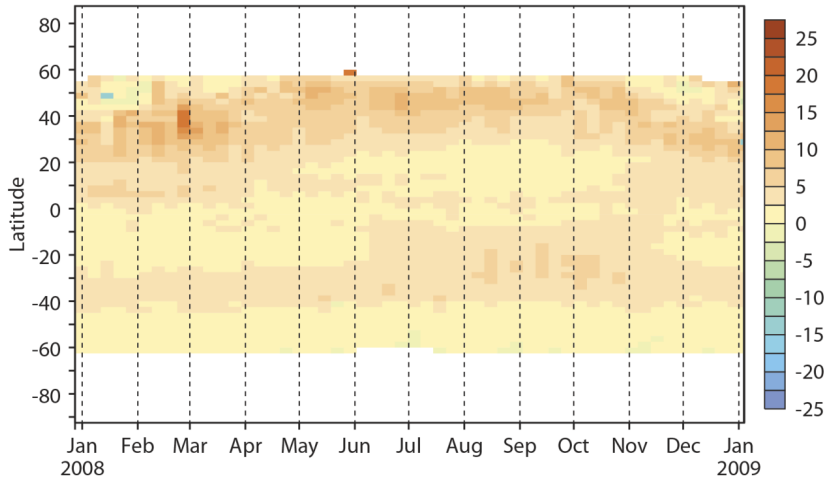

Figure 19. Time series of weekly averaged zonal mean OMI TRCNO2 analysis increment (analysis minus forecast) in \% for 2008 . Red indicates positive values, blue negative values.

emissions, too short lifetime of simulated $\mathrm{NO}_{2}$, and uncertainties in the chemistry, e.g. regarding photolysis rates or modelling of wet and dry deposition. It will have to be investigated how important factors like injection height, diurnal cycle of the emissions and the horizontal model resolution are for correctly modelling the TRCNO2 values in this area. All runs tend to exaggerate the annual cycle for South Africa, where they overestimate $\mathrm{NO}_{2}$ during the biomassburning season. This was already noted for REAN in Inness et al. (2013) and seems to be related to too large $\mathrm{NO}_{x}$ emission factors used in GFAS. The differences between CIFSAN and CIFS-CTRL are small. The largest differences are seen over the eastern US, where CIFS-AN has higher $\mathrm{NO}_{2}$ values than CIFS-CTRL with leads to smaller biases from February to July, and larger biases during the rest of the year.
Figure 23 evaluates $\mathrm{NO}_{2}$ profiles from CIFS-AN and CIFS-CTRL against MAX-DOAS measurements over Beijing from the surface to $3.5 \mathrm{~km}$. The MAX-DOAS instrument is located in the Beijing city centre close the Olympic Stadium and the horizontal extent of the measurements varies between a few and a few dozen of kilometres, depending on the pollution, so the representative error of the model relative to the measurements is bound to be large. Both experiments have a negative $\mathrm{NO}_{2}$ bias, but there is a clear difference between the experiments and a smaller bias in CIFSAN. The mean bias of the partial column is reduced from $-22 \%$ in CIFS-CTRL to $-14 \%$ in CIFS-AN. These values are larger than the mean relative uncertainty for all measurements which is $12 \%$ (Hendrick et al., 2014). The time series of the $\mathrm{NO}_{2}$ columns shows that when there is quite homogeneous urban pollution, e.g. between the end of June and the middle of August, the model fits the observations well. This is not the case in autumn/winter when there are numerous strong local pollution events. Now the pollution background is still well captured by the model but the high $\mathrm{NO}_{2}$ peaks are not (despite some improvements in CIFS-AN). This agrees with the larger underestimation seen in eastern Asia relative to GOME-2 during winter.

\section{Conclusion and future outlook}

A new chemistry transport model, the Composition-IFS (Flemming et al., 2015), was developed as part of the MACC project. This C-IFS model is based on ECMWF's Integrated Forecasting System and includes modules for chemistry, deposition and emissions of reactive gases. Several of the 


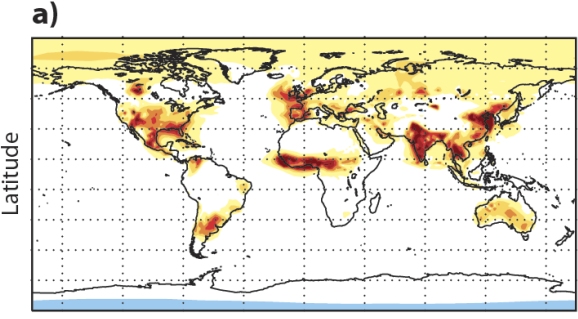

b)

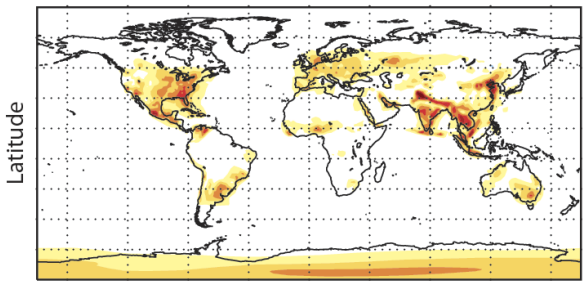

Longitude

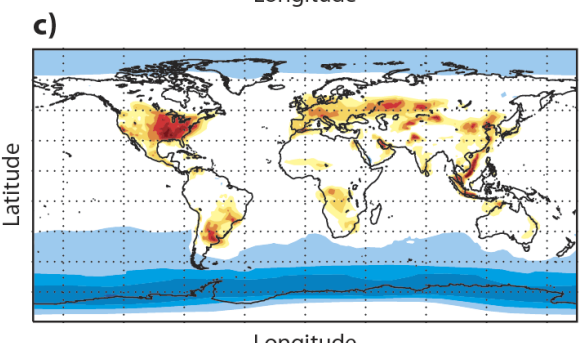

d)

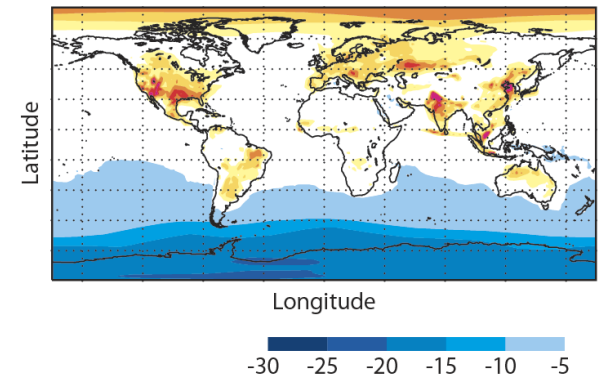

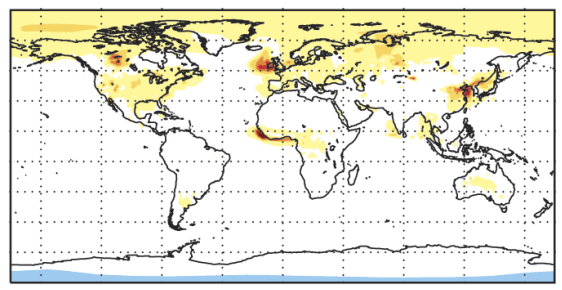

Longitude

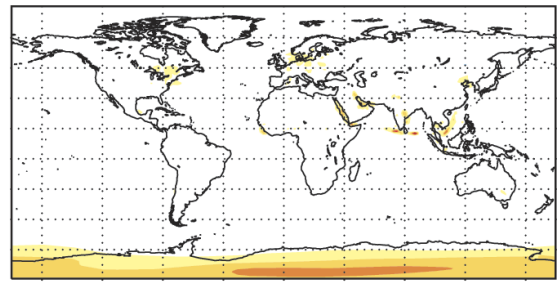

Longitude

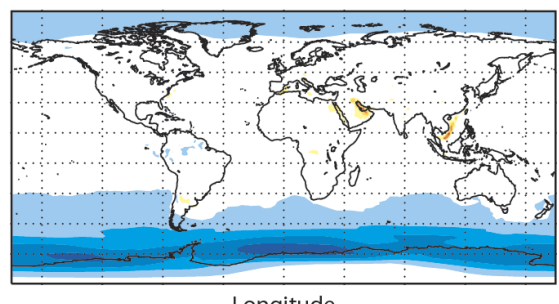

Longitude

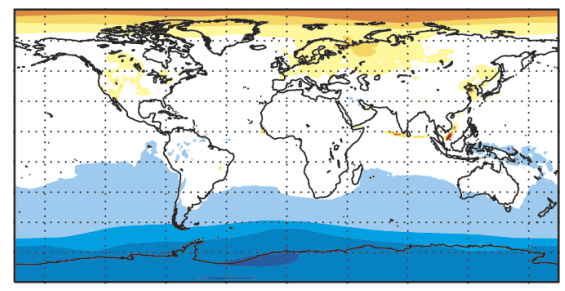

Longitude

$\begin{array}{llllll}10 & 15 & 20 & 25 & 30 & 100\end{array}$

Figure 20. Seasonal mean differences of analysis fields from CIFS-AN minus CIFS-CTRL (left panels) and differences of $12 \mathrm{~h}$ forecasts from CIFS-AN minus CIFS-CTRL (right panels) in $10^{15}$ molec $\mathrm{cm}^{-2}$ for (a) JF, (b) MAM, (c) JJA and (d) SON 2008. Red indicates positive values, blue negative values.

chemistry variables have been included as control variables in the data assimilation part of the IFS so that initial conditions for these fields can be modified by assimilating observations of atmospheric composition. The performance of C-IFS in data assimilation mode was tested by assimilating satellite retrievals of $\mathrm{CO}, \mathrm{O}_{3}$ and $\mathrm{NO}_{2}$ from various sensors (see Table 1) for the year 2008. The results were compared with a control run without data assimilation, with fields from the MACC reanalysis and with independent observations (see Table 2).

Assimilating MOPITT TCCO led to an improved total column CO field compared to the control run, and also to some improvements in the vertical distribution of $\mathrm{CO}$ and the $\mathrm{CO}$ concentrations in the lower troposphere, with the largest im- pact in the NH winter. In the tropics there was also some improvement compared to the control run in surface and lower tropospheric $\mathrm{CO}$ in the C-IFS analysis, particularly during the South African biomass-burning season. The C-IFS analysis captured the seasonal cycle of surface $\mathrm{CO}$ better than the MACC reanalysis at several GAW stations. In future work, it will be tested if the assimilation of MOPITT, IASI or TES CO profiles can help to further correct the 3-dimensional distribution of CO. Furthermore, model runs will be carried out to assess if using the latest GFAS v1.2 biomass-burning emissions, which use a plume rise model to calculate injection heights, can lead to an improved representation of $\mathrm{CO}$ in the lower and mid-troposphere during the tropical biomassburning season. 
a)

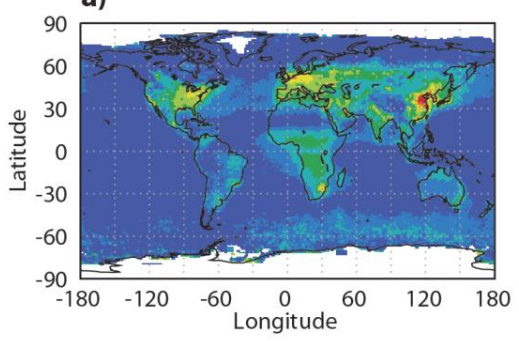

c)

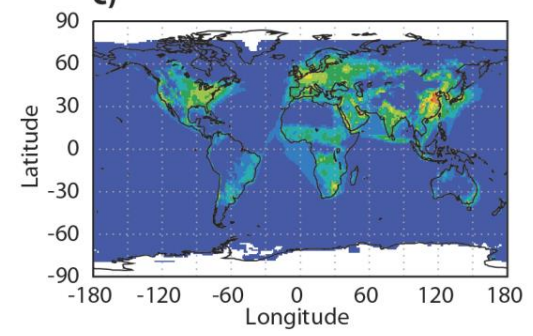

b)

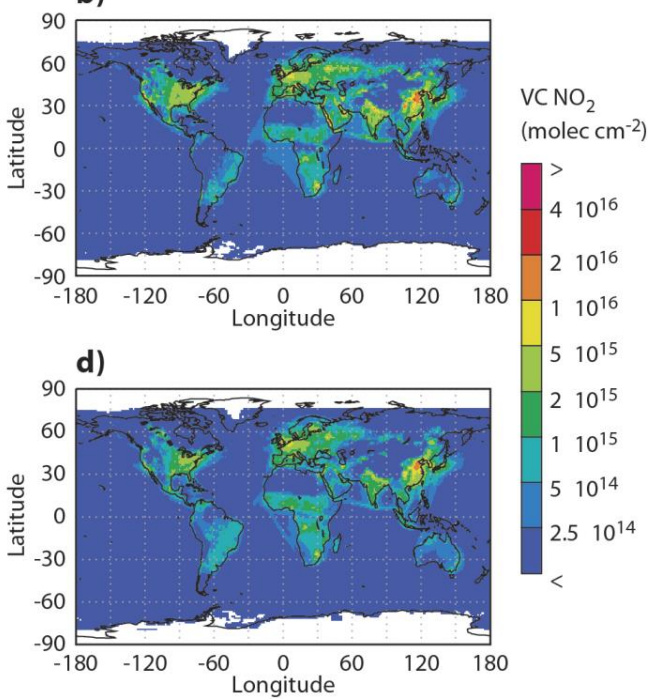

Figure 21. $\mathrm{NO}_{2}$ tropospheric column retrievals for 2008 from (a) GOME-2, (b) CIFS-AN, (c) CIFS-CTRL and (d) REAN in $10^{15}$ molecules $\mathrm{cm}^{-2}$. Red indicates higher values, blue lower values.
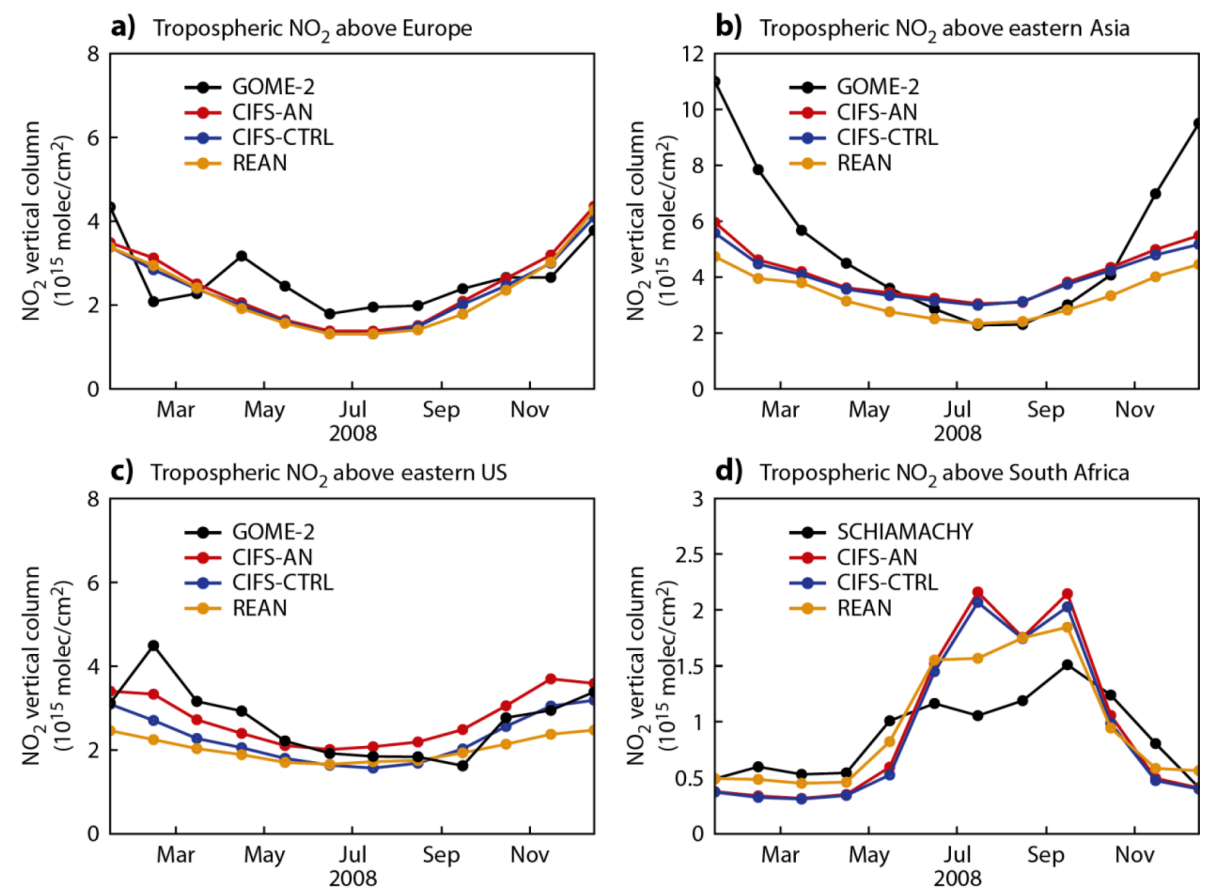

Figure 22. Time series of area-averaged tropospheric $\mathrm{NO}_{2}$ columns from GOME-2 retrievals (black), CIFS-AN (red), CIFS-CTRL (blue) and REAN (orange) for (a) Europe, (b) eastern Asia, (c) eastern US and (d) South-Africa in $10^{15}$ molecules cm ${ }^{-2}$.

The simple stratospheric ozone photochemical parameterization used by the stand alone C-IFS (CB05) system to model the stratospheric ozone field was always designed to be used in a data assimilation context and leads to a very biased stratospheric and total column ozone field in the C-IFS control run. The assimilation of a combination of ozone total column and stratospheric profile retrievals (see Table 1) greatly improves the total column, the stratospheric and the upper tropospheric ozone field in the C-IFS analysis compared to the control run. No tropospheric $\mathrm{O}_{3}$ data were assimilated in our tests. Therefore, the impact on tropospheric $\mathrm{O}_{3}$ came from the residual of total column $\mathrm{O}_{3}$ and the stratospheric profile data, and was smaller in the mid and lower troposphere than in the upper troposphere, as characteristics 

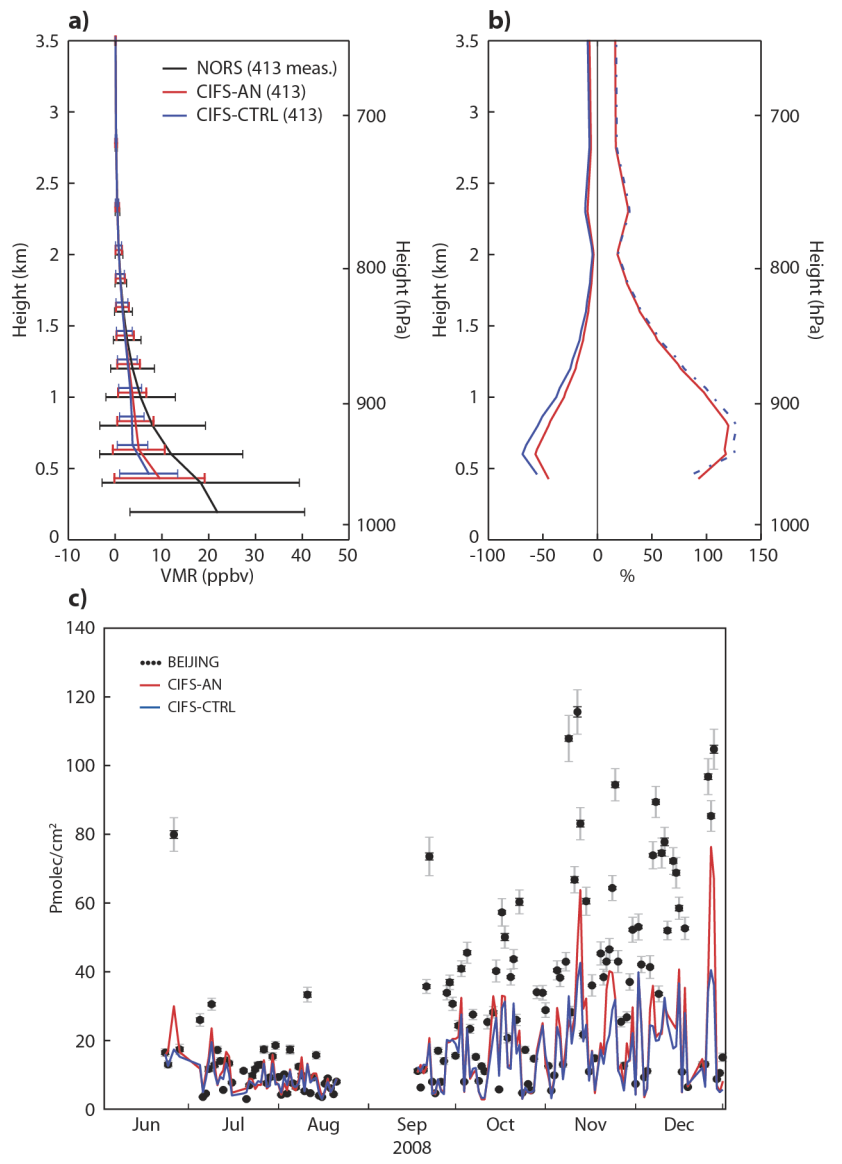

Figure 23. (a) Mean $\mathrm{NO}_{2}$ profiles in ppbv from UVVIS DOAS instrument at Beijing (black), CIFS-AN (red) and CIFS-CTRL (blue); (b) mean bias (solid line) and SD (dotted lines) profiles in \% for the period 1 June-31 December 2008; and (c) time series of daily mean partial $\mathrm{NO}_{2}$ column for the layer between 0.3 and $3.5 \mathrm{~km}$ in $10^{15}$ molecules $\mathrm{cm}^{-2}$. A total of 413 measurements were available during the period.

of the chemistry scheme became more important. For example, a large positive bias in lower tropospheric ozone over eastern Asia was not reduced by the analysis, and there was little impact on lower tropospheric ozone over Europe and North America during the summer. Nevertheless, there was some improvement in the C-IFS analysis in the troposphere and the positive ozone bias seen in the C-IFS control run over Europe and North America during winter and spring in the lower troposphere was reduced. It is planned to test the assimilation of IASI tropospheric $\mathrm{O}_{3}$ columns or IASI $\mathrm{O}_{3}$ profiles in combination with the MLS and ozone column data, which should allow for a better correction of tropospheric ozone (e.g. Emili et al., 2014; Barré et al., 2014). Despite its simple $\mathrm{O}_{3}$ chemistry parameterization the $\mathrm{C}$-IFS $\mathrm{O}_{3}$ analysis was of similar quality to the MACC reanalysis which used a more comprehensive stratospheric ozone chemistry scheme.
The impact of the assimilation of tropospheric $\mathrm{NO}_{2}$ column retrievals was small because of the short lifetime of $\mathrm{NO}_{2}$. Even though the assimilation led to large analysis increments this information was not retained by the model, and most of the impact of the data assimilation was lost from one analysis cycle to the next. It might be possible to improve this slightly by using a shorter assimilation window, e.g. $6 \mathrm{~h}$ 4D-Var, and by using $\mathrm{NO}_{2}$ retrievals from more than one satellite with different overpass times, but ideally the $\mathrm{NO}_{2}$ data should be used to adjust the emissions instead of or in addition to the initial conditions. Compared to GOME2 TRCNO2 retrievals, C-IFS with and without assimilation of OMI TRCNO2 data severely underestimated wintertime $\mathrm{NO}_{2}$ over eastern Asia and overestimated $\mathrm{NO}_{2}$ over southern Africa during the biomass-burning season. At other times and in other regions the agreement was better. An underestimation was also found with respect to MAX-DOAS observations at Beijing. However, in order to increase the statistical significance of the validation effort using MAX-DOAS data, comparisons will be further extended to other stations.

A future study could look at the model response of one assimilated component to another, e.g. the response of model $\mathrm{O}_{3}$ to the assimilation of $\mathrm{NO}_{2}$ and $\mathrm{CO}$ data. This could be a first step towards investigating the interactions between the different chemical species before assessing the impact of cross correlations in the assimilation of multiple chemical species. Further plans for the development of the C-IFS data assimilation system include the recalculation of the background error statistics for all MACC control variables with the latest configuration of the model, to include emissions in the control vector so that they can be adjusted in addition to the initial conditions, especially for $\mathrm{NO}_{2}$, and to investigate the impact of the chemical assimilation on the wind field, which has been suppressed so far.

In data assimilation mode C-IFS performs similarly well or better than the coupled system used in the MACC reanalysis for $\mathrm{CO}, \mathrm{O}_{3}$ and $\mathrm{NO}_{2}$, especially in the lower troposphere and at the surface. Based on many tests and comparisons the MACC pre-operational NRT system has now been switched to C-IFS (CB05) to provide daily routine global analysis and forecast fields. The reduced numerical cost of C-IFS (Flemming et al., 2015) will allow to run this system at higher resolution which may lead to additional improvements in the forecasted fields.

One limitation of the current C-IFS (CB05) system is that it does not contain a comprehensive stratospheric chemistry scheme, and this paper has shown the resulting problems for stratospheric ozone in the C-IFS control run. While a good stratospheric ozone analysis can be obtained by using a simple stratospheric ozone photochemical parameterization and assimilating ozone observations, other stratospheric species are not available or poorly constrained in C-IFS (CB05). Work is under way to extend the C-IFS (CB05) scheme with the stratospheric chemical mechanism of the Belgian Assimilation System for Chemical ObsErvations (BASCOE) 
scheme (Errera et al., 2008). This will yield a CTM that can model both the troposphere and the stratosphere. Furthermore, the MOZART and MOCAGE chemistry schemes, which have tropospheric and stratospheric chemistry solvers, are also being implemented into the C-IFS, so that in the near future the C-IFS system might be able to provide comprehensive analyses and forecasts of the troposphere and the stratosphere by an ensemble of CTMs.

\section{The Supplement related to this article is available online at doi:10.5194/acp-15-5275-2015-supplement.}

Acknowledgements. MACC-II was funded by the European Commission under the EU Seventh Research Framework Programme, contract number 283576. MACC-III was funded by the European Commission under Horizon2020 as a Coordination \& Support Action, grant agreement number 633080. Ground-based data used in this publication were obtained as part of WMO's Global Atmosphere Watch (GAW) and its contributing Network for the Detection of Atmospheric Composition Change (NDACC), in particular the FTIR CO data from Eureka, Jungfraujoch, Izaña and Lauder, and Southern Hemisphere Additional Ozonesonde programme (SHADOZ). Their consolidated version is available publicly through the NDACC Data Host Facility (http://ndacc. org), SHADOZ archive (http://croc.gsfc.nasa.gov/shadoz/), and the World Ozone and Ultraviolet Radiation Data Centre (WOUDC, http://woudc.org).

The evaluations with the NDACC FTIR CO and UVVIS DOAS $\mathrm{NO}_{2}$ measurement were performed within the framework of the NORS project (Demonstration Network Of ground-based Remote Sensing observations in support of the Copernicus Atmospheric Service, funded under the European Community's Seventh Research Framework Programme, grant no. 284421). We acknowledge the contribution of Michel Van Roozendael in setting up the MAX/DOAS instrument in Beijing and in participating to the retrieving of the $\mathrm{NO}_{2}$ data at this new station.

Edited by: W. Lahoz

\section{References}

Andersson, E. and Järvinen, H.: Variational quality control, Q. J. Roy. Meteorol. Soc., 125, 697-722, 1999.

Arellano Jr., A. F., Raeder, K., Anderson, J. L., Hess, P. G., Emmons, L. K., Edwards, D. P., Pfister, G. G., Campos, T. L., and Sachse, G. W.: Evaluating model performance of an ensemblebased chemical data assimilation system during INTEX-B field mission, Atmos. Chem. Phys., 7, 5695-5710, doi:10.5194/acp-75695-2007, 2007.

Barbu, A., Segers, A., Schaap, M., Heemink, A., and Builtjes, P. J. H.: A multi-component data assimilation experiment directed to sulphur dioxide and sulphate over Europe, Atmos. Environ., 43, 1622-1631, doi:10.1016/j.atmosenv.2008.12.005, 2009.
Barré, J., Peuch, V.-H., Lahoz, W. A., Attié, J.-L., Josse, B., Piacentini, A., Eremenko, M., Dufour, G., Nedelec, P., von Clarmann, T., and El Amraoui, L.: Combined data assimilation of ozone tropospheric columns and stratospheric profiles in a high-resolution CTM, Q. J. Roy. Meteorol. Soc., 140, 966-981, doi:10.1002/qj.2176, 2014.

Benedetti, A., Morcrette, J.-J., Boucher, O., Dethof, A., Engelen, R. J., Fisher, M., Flentje, H., Huneeus, N., Jones, L., Kaiser, J. W., Kinne, S., Mangold, A., Razinger, M., Simmons, A. J., Suttie, M., and the GEMS-AER team: Aerosol analysis and forecast in the European Centre for Medium-Range Weather Forecasts Integrated Forecast System: Data Assimilation, J. Geophys. Res., D13205, 114, doi:10.1029/2008JD011115, 2009.

Bhartia, P. K. and Wellemeyer, C.: TOMS-V8 Total $O_{3}$ algorithm, in: OMI ozone product ATBD Volume II, NASA Goddard Space Flight Center, Greenbelt, MD, USA, 2002.

Bhartia, P. K., McPeters, R. D., Mateer, C. L., Flynn, L. E., and Wellemeyer, C.: Algorithm for the estimation of vertical ozone profiles from the backscattered uLTaviolet technique, J. Geophys. Res., 101, 18793-18806, 1996.

Cariolle, D. and Teyssèdre, H.: A revised linear ozone photochemistry parameterization for use in transport and general circulation models: multi-annual simulations, Atmos. Chem. Phys., 7, $2183-$ 2196, doi:10.5194/acp-7-2183-2007, 2007.

Carmichael, G. R., Chai, T., Sandu, A., Constantinescu, E. M., and Daescu, D.: Predicting air quality: Improvements through advanced methods to integrate models and measurements, J. Comp. Phys., 227, 7, doi:10.1016/j.jcp.2007.02.024, 2008.

Chai, T., Carmichael, G. R., Tang, Y. , Sandu, A., Hardesty, M., Pilewskie, P., Whitlow, S., Browell, E. V., Avery, M. A., Nedelec, P., Merrill, J. T., Thompson, A. M., and Williams, E.: Fourdimensional data assimilation experiments with International Consortium for Atmospheric Research on Transport and Transformation ozone measurements, J. Geophys. Res., 112, D12S15, doi:10.1029/2006JD007763, 2007.

Courtier, P., Thépaut, J.-N., and Hollingsworth, A.: A strategy for operational implementation of 4D-Var, using an incremental approach, Q. J. Roy. Meteorol. Soc., 120, 1367-1388, 1994.

Dee, D. P. and Uppala, S.: Variational bias correction of satellite radiance data in the ERA-Interim reanalysis, Q. J. Roy. Meteorol. Soc., 135, 1830-1841, 2009.

Deeter, M. N., Edwards, D. P., Gille, G. C., Emmons, L. K., Francis, G., Ho, S.-P., Mao, D., Masters, D., Worden, H., Drummond, J. R., and Novelli, P. C.: The MOPITT version 4 CO product: Algorithm enhancements, validation, and long-term stability, J. Geophys. Res., 115, D07306, doi:10.1029/2009JD013005, 2010.

Deeter, M. N., Martínez-Alonso, S., Edwards, D. P. , Emmons, L. K., Gille, J. C. , Worden, H. M., Pittman, J. V., Daube, B. C., and Wofsy, S. C.: Validation of MOPITT Version 5 thermalinfrared, near-infrared, and multispectral carbon monoxide profile retrievals for 2000-2011, J. Geophys. Res.-Atmos., 118, 6710-6725, doi:10.1002/jgrd.50272, 2013.

de Laat, A. T. J., Gloudemans, A. M. S., Schrijver, H., Aben, I., Nagahama, Y., Suzuki, K., Mahieu, E., Jones, N. B., Paton-Walsh, C., Deutscher, N. M., Griffith, D. W. T., De Mazière, M., Mittermeier, R. L., Fast, H., Notholt, J., Palm, M., Hawat, T., Blumenstock, T., Hase, F., Schneider, M., Rinsland, C., Dzhola, A. V., Grechko, E. I., Poberovskii, A. M., Makarova, M. V., Mellqvist, J., Strandberg, A., Sussmann, R., Borsdorff, T., and Rettinger, 
M.: Validation of five years (2003-2007) of SCIAMACHY CO total column measurements using ground-based spectrometer observations, Atmos. Meas. Tech., 3, 1457-1471, doi:10.5194/amt3-1457-2010, 2010.

Dethof, A. and Hólm, E. V.: Ozone assimilation in the ERA-40 reanalysis project, Q. J. Roy. Meteorol. Soc., 130, 2851-2872, 2004.

Dils, B., De Mazière, M., Müller, J. F., Blumenstock, T., Buchwitz, M., de Beek, R., Demoulin, P., Duchatelet, P., Fast, H., Frankenberg, C., Gloudemans, A., Griffith, D., Jones, N., Kerzenmacher, T., Kramer, I., Mahieu, E., Mellqvist, J., Mittermeier, R. L., Notholt, J., Rinsland, C. P., Schrijver, H., Smale, D., Strandberg, A., Straume, A. G., Stremme, W., Strong, K., Sussmann, R., Taylor, J., van den Broek, M., Velazco, V., Wagner, T., Warneke, T., Wiacek, A., and Wood, S.: Comparisons between SCIAMACHY and ground-based FTIR data for total columns of $\mathrm{CO}, \mathrm{CH}_{4}, \mathrm{CO}_{2}$ and $\mathrm{N}_{2} \mathrm{O}$, Atmos. Chem. Phys., 6, 1953-1976, doi:10.5194/acp6-1953-2006, 2006.

Dragani, R.: On the quality of the ERA-Interim ozone reanalyses: comparisons with satellite data, Q. J. Roy. Meteorol. Soc., 137, 1312-1326, doi:10.1002/qj.821, 2011.

Dupuy, E., Walker, K. A., Kar, J., Boone, C. D., McElroy, C. T., Bernath, P. F., Drummond, J. R., Skelton, R., McLeod, S. D., Hughes, R. C., Nowlan, C. R., Dufour, D. G., Zou, J., Nichitiu, F., Strong, K., Baron, P., Bevilacqua, R. M., Blumenstock, T., Bodeker, G. E., Borsdorff, T., Bourassa, A. E., Bovensmann, H., Boyd, I. S., Bracher, A., Brogniez, C., Burrows, J. P., Catoire, V., Ceccherini, S., Chabrillat, S., Christensen, T., Coffey, M. T., Cortesi, U., Davies, J., De Clercq, C., Degenstein, D. A., De Mazière, M., Demoulin, P., Dodion, J., Firanski, B., Fischer, H., Forbes, G., Froidevaux, L., Fussen, D., Gerard, P., GodinBeekmann, S., Goutail, F., Granville, J., Griffith, D., Haley, C. S., Hannigan, J. W., Höpfner, M., Jin, J. J., Jones, A., Jones, N. B., Jucks, K., Kagawa, A., Kasai, Y., Kerzenmacher, T. E., Kleinböhl, A., Klekociuk, A. R., Kramer, I., Küllmann, H., Kuttippurath, J., Kyrölä, E., Lambert, J.-C., Livesey, N. J., Llewellyn, E. J., Lloyd, N. D., Mahieu, E., Manney, G. L., Marshall, B. T., McConnell, J. C., McCormick, M. P., McDermid, I. S., McHugh, M., McLinden, C. A., Mellqvist, J., Mizutani, K., Murayama, Y., Murtagh, D. P., Oelhaf, H., Parrish, A., Petelina, S. V., Piccolo, C., Pommereau, J.-P., Randall, C. E., Robert, C., Roth, C., Schneider, M., Senten, C., Steck, T., Strandberg, A., Strawbridge, K. B., Sussmann, R., Swart, D. P. J., Tarasick, D. W., Taylor, J. R., Tétard, C., Thomason, L. W., Thompson, A. M., Tully, M. B., Urban, J., Vanhellemont, F., Vigouroux, C., von Clarmann, T., von der Gathen, P., von Savigny, C., Waters, J. W., Witte, J. C., Wolff, M., and Zawodny, J. M.: Validation of ozone measurements from the Atmospheric Chemistry Experiment (ACE), Atmos. Chem. Phys., 9, 287-343, doi:10.5194/acp-9-287-2009, 2009.

Elbern, H. and Schmidt, H.: A four-dimensional variational chemistry data assimilation scheme for Eulerian chemistry transport modeling, J. Geophys. Res., 104, 18583-18598, 1999.

Elbern, H. and Schmidt, H.: Ozone episode analysis by fourdimensional variational chemistry data assimilation. J. Geophys. Res., 106, 3569-3590, 2001.

Elbern, H., Schmidt, H., and Ebel, A.: Variational data assimilation for tropospheric chemistry modeling, J. Geophys. Res., 102, 15967-15985, 1997.
Elbern, H., Schmidt, H., Talagrand, O., and Ebel, A.: 4D-variational data assimilation with an adjoint air quality model for emission analysis, Environ. Model. Softw., 15, 539-548, 2000.

Elbern, H., Strunk, A., Schmidt, H., and Talagrand, O.: Emission rate and chemical state estimation by 4-dimensional variational inversion, Atmos. Chem. Phys., 7, 3749-3769, doi:10.5194/acp7-3749-2007, 2007.

Emili, E., Barret, B., Massart, S., Le Flochmoen, E., Piacentini, A., El Amraoui, L., Pannekoucke, O., and Cariolle, D.: Combined assimilation of IASI and MLS observations to constrain tropospheric and stratospheric ozone in a global chemical transport model, Atmos. Chem. Phys., 14, 177-198, doi:10.5194/acp-14177-2014, 2014.

Errera, Q. and Fonteyn, D.: Four-dimensional variational chemical assimilation of CRISTA stratospheric measurements. J. Geophys. Res., 106, 12253-12265, 2001.

Errera, Q., Daerden, F., Chabrillat, S., Lambert, J. C., Lahoz, W. A., Viscardy, S., Bonjean, S., and Fonteyn, D.: 4D-Var assimilation of MIPAS chemical observations: ozone and nitrogen dioxide analyses, Atmos. Chem. Phys., 8, 6169-6187, doi:10.5194/acp8-6169-2008, 2008.

Eskes, H. J., van Velthoven, P. F. J., and Kelder, H. M.: Global ozone forecasting based on ERS-2 GOME observations, Atmos. Chem. Phys., 2, 271-278, doi:10.5194/acp-2-271-2002, 2002.

Eskes, H., van Velthoven, P., Valks, P., and Kelder, P. H.: Assimilation of GOME total ozone satellite observations in a threedimensional tracer transport model, Q. J. Roy. Meteorol. Soc., 129, 1663-1681, doi:10.1256/qj.02.14, 2003.

Fisher, M.: Generalized frames on the sphere with application to background error covariance modelling, Seminar on resent developments in numerical methods for atmospheric and ocean modelling, 6-10 September 2004, Proceedings, ECMWF, pp. 87-101, available from ECMWF, Shinfield Park, Reading, Berkshire, RG2 9AX, UK, 2004.

Fisher, M.: Wavelet $\mathrm{Jb}$ - A new way to model the statistics of background errors, ECMWF Newsletter, 106, 23-28, available from ECMWF, Shinfield Park, Reading, Berkshire, RG2 9AX, UK, 2006.

Fisher, M. and Lary, D. J.: Lagrangian four-dimensional variational data assimilation of chemical species, Q. J. Roy. Meteorol. Soc., 121, 1681-1704, 1995.

Flemming, J. and Inness, A.: Volcanic sulfur dioxide plume forecasts based on UV satellite retrievals for the 2011 Grímsvötn and the 2010 Eyjafjallajökull eruption, J. Geophys. Res.-Atmos., 118, 1-18, doi:10.1002/jgrd.50753, 2013.

Flemming, J., Inness, A., Flentje, H., Huijnen, V., Moinat, P., Schultz, M. G., and Stein, O.: Coupling global chemistry transport models to ECMWF's integrated forecast system, Geosci. Model Dev., 2, 253-265, doi:10.5194/gmd-2-253-2009, 2009.

Flemming, J., Peuch, V.-H., Engelen, R., and Kaiser, J. W.: A European Global-to-Regional Air Pollution Forecasting System that Combines Modeling with Satellite Observations, EM Magazine of A\&WMA, p. 6-10, https://www.researchgate.net/publication/259535688_A_ European_Global-toRegional_Air_Pollution_Forecasting System_that_Combines_Modeling_with_Satellite_Observations (last access: 11 May 2015), November 2013.

Flemming, J., Huijnen, V., Arteta, J., Bechtold, P., Beljaars, A., Blechschmidt, A.-M., Diamantakis, M., Engelen, R. J., Gaudel, 
A., Inness, A., Jones, L., Josse, B., Katragkou, E., Marecal, V., Peuch, V.-H., Richter, A., Schultz, M. G., Stein, O., and Tsikerdekis, A.: Tropospheric chemistry in the Integrated Forecasting System of ECMWF, Geosci. Model Dev., 8, 975-1003, doi:10.5194/gmd-8-975-2015, 2015.

Fortems-Cheiney, A., Chevallier, F., Pison, I., Bousquet, P., Szopa, S., Deeter, M. N., and Clerbaux, C.: Ten years of $\mathrm{CO}$ emissions as seen from Measurements of Pollution in the Troposphere (MOPITT), J. Geophys. Res., 116, D05304, doi:10.1029/2010JD014416, 2011.

Gaubert, B., Coman, A., Foret, G., Meleux, F., Ung, A., Rouil, L., Ionescu, A., Candau, Y., and Beekmann, M.: Regional scale ozone data assimilation using an ensemble Kalman filter and the CHIMERE chemical transport model, Geosci. Model Dev., 7, 283-302, doi:10.5194/gmd-7-283-2014, 2014.

Geer, A. J., Peubey, C., Bannister, R. N., Brugge, R., Jackson, D. R., Lahoz, W. A., Migliorini, S., O'Neill, A., and Swinbank, R.: Assimilation of stratospheric ozone from MIPAS into a global general-circulation model: The September 2002 vortex split, Q. J. Roy. Meteorol. Soc., 132, 231-257, doi:10.1256/qj.04.181, 2006.

George, M., Clerbaux, C., Bouarar, I., Coheur, P. F., Deeter, M. N., Edwards, D. P., Francis, G., Gille, J. C., Hadji-Lazaro, J., Hurtmans, D., Inness, A., Mao, D., and Worden, H. M.: An examination of the long-term CO records from MOPITT and IASI: comparison of retrieval methodology, Atmos. Meas. Technol. Discuss., submitted, 2015.

Granier, C., Guenther, A., Lamarque, J., Mieville, A., Muller, J., Olivier, J., Orlando, J., Peters, J., Petron, G., Tyndall, G., and Wallens, S.: POET, a database of surface emissions of ozone precursors, available at: http://www.aero.jussieu.fr/projet/ ACCENT/POET.php (last access: December 2014), 2005.

Granier, C., Bessagnet, B., Bond, T., D’Angiola, A., Denier van der Gon, H., Frost, G. J., Heil, A., Kaiser, J. W., Kinne, S., Klimont, Z., Kloster,S., Lamarque, J.-F., Liousse, C., Masui, T., Meleux, F., Mieville, A., Ohara, R., Raut, J.-C., Riahi, K., Schultz, M. G., Smith, S. G., Thompson, A., van Aardenne, J., van der Werf, G. R., and van Vuuren, D. P.: Evolution of anthropogenic and biomass burning emissions of air pollutants at global and regional scales during the 1980-2010 period, Clim. Change, 109, 163-190, doi:10.1007/s10584-011-0154-1, 2011.

Guenther, A., Karl, T., Harley, P., Wiedinmyer, C., Palmer, P. I., and Geron, C.: Estimates of global terrestrial isoprene emissions using MEGAN (Model of Emissions of Gases and Aerosols from Nature), Atmos. Chem. Phys., 6, 3181-3210, doi:10.5194/acp-63181-2006, 2006.

Hanea, R. G., Velders, G. J. M., and Heemink, A.: Data assimilation of ground-level ozone in Europe with a Kalman filter and chemistry transport model, J. Geophys. Res., 109, D10302, doi:10.1029/2003JD004283, 2004.

Hendrick, F., Müller, J.-F., Clémer, K., Wang, P., De Mazière, M., Fayt, C., Gielen, C., Hermans, C., Ma, J. Z., Pinardi, G., Stavrakou, T., Vlemmix, T., and Van Roozendael, M.: Four years of ground-based MAX-DOAS observations of HONO and $\mathrm{NO}_{2}$ in the Beijing area, Atmos. Chem. Phys., 14, 765-781, doi:10.5194/acp-14-765-2014, 2014.

Hollingsworth, A., Engelen, R. J., Textor, C., Benedetti, A., Boucher, O., Chevallier, F., Dethof, A., Elbern, H., Eskes, H., Flemming, J., Granier, C., Kaiser, J. W., Morcrette, J.-
J., Rayner, R., Peuch, V.-H., Rouil, L., Schultz, M. G., Simmons, A. J., and The GEMS Consortium: Toward a Monitoring and Forecasting System For Atmospheric Composition: The GEMS Project, B. Am. Meteorol. Soc., 89, 1147-1164, doi:10.1175/2008BAMS2355.1, 2008.

Hólm, E. V., Untch, A., Simmons, A., Saunders, R., Bouttier, F., and Andersson, E.: Multivariate ozone assimilation in fourdimensional data assimilation, p. 89-94 in Proceedings of the Soda Workshop on Chemical Data Assimilation, 9-10 December 1998, KNMI, De Bilt, the Netherlands, 1999.

Hooghiemstra, P. B., Krol, M. C., Meirink, J. F., Bergamaschi, P., van der Werf, G. R., Novelli, P. C., Aben, I., and Röckmann, T.: Optimizing global $\mathrm{CO}$ emission estimates using a four-dimensional variational data assimilation system and surface network observations, Atmos. Chem. Phys., 11, 4705-4723, doi:10.5194/acp-11-4705-2011, 2011.

Huijnen, V., Eskes, H. J., Poupkou, A., Elbern, H., Boersma, K. F., Foret, G., Sofiev, M., Valdebenito, A., Flemming, J., Stein, O., Gross, A., Robertson, L., D’Isidoro, M., Kioutsioukis, I., Friese, E., Amstrup, B., Bergstrom, R., Strunk, A., Vira, J., Zyryanov, D., Maurizi, A., Melas, D., Peuch, V.-H., and Zerefos, C.: Comparison of $\mathrm{OMI} \mathrm{NO}_{2}$ tropospheric columns with an ensemble of global and European regional air quality models, Atmos. Chem. Phys., 10, 3273-3296, doi:10.5194/acp-10-3273-2010, 2010 a.

Huijnen, V., Williams, J., van Weele, M., van Noije, T., Krol, M., Dentener, F., Segers, A., Houweling, S., Peters, W., de Laat, J., Boersma, F., Bergamaschi, P., van Velthoven, P., Le Sager, P., Eskes, H., Alkemade, F., Scheele, R., Nédélec, P., and Pätz, H.-W.: The global chemistry transport model TM5: description and evaluation of the tropospheric chemistry version 3.0, Geosci. Model Dev., 3, 445-473, doi:10.5194/gmd-3-445-2010, 2010b.

Huijnen, V., Williams, J. E., and Flemming, J.: Modeling global impacts of heterogeneous loss of $\mathrm{HO}_{2}$ on cloud droplets, ice particles and aerosols, Atmos. Chem. Phys. Discuss., 14, 8575-8632, doi:10.5194/acpd-14-8575-2014, 2014.

Inness, A., Flemming, J., Suttie, M., and Jones, L.: GEMS data assimilation system for chemically reactive gases. ECMWF RD Tech Memo 587, available at: http://old.ecmwf.int/publications/ library/ecpublications/_pdf/tm/501-600/tm587.pdf (last access: December 2014), 2009.

Inness, A., Baier, F., Benedetti, A., Bouarar, I., Chabrillat, S., Clark, H., Clerbaux, C., Coheur, P., Engelen, R. J., Errera, Q., Flemming, J., George, M., Granier, C., Hadji-Lazaro, J., Huijnen, V., Hurtmans, D., Jones, L., Kaiser, J. W., Kapsomenakis, J., Lefever, K., Leitão, J., Razinger, M., Richter, A., Schultz, M. G., Simmons, A. J., Suttie, M., Stein, O., Thépaut, J.-N., Thouret, V., Vrekoussis, M., Zerefos, C., and the MACC team: The MACC reanalysis: an $8 \mathrm{yr}$ data set of atmospheric composition, Atmos. Chem. Phys., 13, 4073-4109, doi:10.5194/acp-13-4073-2013, 2013.

Jacob, D. J., Liu, H., Mari, C., and Yantosca, R. M.: Harvard wet deposition scheme for GMI, Harvard University Atmospheric Chemistry Modeling Group, revised March 2000, available at: http://acmg.seas.harvard.edu/geos/wiki_docs/deposition/ wetdep.jacob_etal_2000.pdf (last access: December 2014), 2000.

Kaiser, J. W., Heil, A., Andreae, M. O., Benedetti, A., Chubarova, N., Jones, L., Morcrette, J.-J., Razinger, M., Schultz, M. G., Suttie, M., and van der Werf, G. R.: Biomass burning emis- 
sions estimated with a global fire assimilation system based on observed fire radiative power, Biogeosciences, 9, 527-554, doi:10.5194/bg-9-527-2012, 2012.

Khattatov, B. V., Lamarque, J.-F., Lyjak, L. V., Ménard, R., Levelt, P., Tie, X., Brasseur, G., and Gille, J. C.: Assimilation of sattelite observations of long-lived chemical species in global chemistry transport models, J. Geophys. Res., 105, 29135-29144, 2000.

Kinnison, D. E., Brasseur, G. P., Walters, S., Garcia, R. R., Marsh, D. R., Sassi, F., Harvey, V. L., Randall, C. E., Emmons, L., Lamarque, J. F., Hess, P., Orlando, J. J., Tie, X. X., Randel, W., Pan, L. L., Gettelman, A., Granier, C., Diehl, T., Niemeier, U., and Simmons, A. J.: Sensitivity of Chemical Tracers to Meteorological Parameters in the MOZART-3 Chemical Transport Model, J. Geophys. Res., 112, D03303, doi:10.1029/2008JD010739, 2007.

Klonecki, A., Pommier, M., Clerbaux, C., Ancellet, G., Cammas, J.-P., Coheur, P.-F., Cozic, A., Diskin, G. S., Hadji-Lazaro, J., Hauglustaine, D. A., Hurtmans, D., Khattatov, B., Lamarque, J.F., Law, K. S., Nedelec, P., Paris, J.-D., Podolske, J. R., Prunet, P., Schlager, H., Szopa, S., and Turquety, S.: Assimilation of IASI satellite $\mathrm{CO}$ fields into a global chemistry transport model for validation against aircraft measurements, Atmos. Chem. Phys., 12, 4493-4512, doi:10.5194/acp-12-4493-2012, 2012.

Komhyr,W. D., Barnes, R. A., Borthers, G. B., Lathrop, J. A., Kerr, J. B., and Opperman, D. P.: Electrochemical concentration cell ozonesonde performance evaluation during STOIC 1989, J. Geophys. Res., 100, 9231-9244, 1995

Kopacz, M., Jacob, D. J., Fisher, J. A., Logan, J. A., Zhang, L., Megretskaia, I. A., Yantosca, R. M., Singh, K., Henze, D. K., Burrows, J. P., Buchwitz, M., Khlystova, I., McMillan, W. W., Gille, J. C., Edwards, D. P., Eldering, A., Thouret, V., and Nedelec, P.: Global estimates of $\mathrm{CO}$ sources with high resolution by adjoint inversion of multiple satellite datasets (MOPITT, AIRS, SCIAMACHY, TES), Atmos. Chem. Phys., 10, 855-876, doi:10.5194/acp-10-855-2010, 2010.

Lahoz, W. A., Geer, A. J., Bekki, S., Bormann, N., Ceccherini, S., Elbern, H., Errera, Q., Eskes, H. J., Fonteyn, D., Jackson, D. R., Khattatov, B., Marchand, M., Massart, S., Peuch, V.-H., Rharmili, S., Ridolfi, M., Segers, A., Talagrand, O., Thornton, H. E., Vik, A. F., and von Clarmann, T.: The Assimilation of Envisat data (ASSET) project, Atmos. Chem. Phys., 7, 1773-1796, doi:10.5194/acp-7-1773-2007, 2007.

Lamarque, J.-F., Khattatov, B. V., Gille, J. C., and Brasseur, G. P.: Assimilation of Measurement of Air Pollution from Space (MAPS) CO in a global three-dimensional model, J. Geophys. Res., 104, 26209-26218, 1999.

Langerock, B., De Mazière, M., Hendrick, F., Vigouroux, C., Desmet, F., Dils, B., and Niemeijer, S.: Description of algorithms for co-locating and comparing gridded model data with remote-sensing observations, Geosci. Model Dev., 8, 911-921, doi:10.5194/gmd-8-911-2015, 2015.

Lefever, K., van der A, R., Baier, F., Christophe, Y., Errera, Q., Eskes, H., Flemming, J., Inness, A., Jones, L., Lambert, J.C., Langerock, B., Schultz, M. G., Stein, O., Wagner, A., and Chabrillat, S.: Copernicus stratospheric ozone service, 20092012: validation, system intercomparison and roles of input data sets, Atmos. Chem. Phys., 15, 2269-2293, doi:10.5194/acp-152269-2015, 2015.
Levelt, P. F., Hilsenrath, E., Leppelmeier, G. W., van den Oord, G. H. J., Bhartia, P. K., Tamminen, J., de Haan, J. F., and Veefkind, J. P.: Science objectives of the Ozone Monitoring Instrument, IEEE Trans. Geosci. Remote Sens., 44, 1199-1208, doi:10.1109/TGRS.2006.872336, 2006

Liu, H., Jacob, D. J., Bey, I., and Yantosca, R. M.: Constraints from $210 \mathrm{~Pb}$ and $7 \mathrm{Be}$ on wet deposition and transport in a global threedimensional chemical tracer model driven by assimilated meteorological fields, J. Geophys. Res., 106, 12109-12128, 2001.

Mahfouf, J.-F. and Rabier, F.: The ECMWF operational implementation of four-dimensional variationalassimilation. II: Experimental results with improved physics, Q. J. Roy. Meteorol. Soc., 126, 1171-1190, 2000.

Marenco, A., Thouret, V., Nédélec, P., Smit, H. G., Helten, M., Kley, D., Karcher, F., Simon, P., Law, K., Pyle, J., Poschmann, G., Von Wrede, R., Hume, C., and Cook, T.: Measurement of ozone and water vapour by Airbus in-service aircraft : The MOZAIC airborne programme, an overview, J. Geophys. Res., 103, 2563125642, 1998.

Massart, S., Agusti-Panareda, A., Aben, I., Butz, A., Chevallier, F., Crevoisier, C., Engelen, R., Frankenberg, C., and Hasekamp, O.: Assimilation of atmospheric methane products into the MACC-II system: from SCIAMACHY to TANSO and IASI, Atmos. Chem. Phys., 14, 6139-6158, doi:10.5194/acp-14-6139-2014, 2014.

Ménard, R., Cohn, S. E., Chang, L.-P., and Lyster, P. M.: Assimilation of stratospheric chemical tracer observations using a Kalman Filter. Part I: Formulation, Mon. Weather Rev., 128, 2654-2671, 2000.

Michou, M., Laville, P., Serça, D., Fotiadi, A., Bouchou, P., and Peuch, V.-H.: Measured and modeled dry deposition velocities over the ESCOMPTE area, Atmos. Res., 74, 89-116, 2004.

Miyazaki, K., Eskes, H. J., and Sudo, K.: Global $\mathrm{NO}_{\mathrm{x}}$ emission estimates derived from an assimilation of OMI tropospheric $\mathrm{NO}_{2}$ columns, Atmos. Chem. Phys., 12, 2263-2288, doi:10.5194/acp12-2263-2012, 2012a.

Miyazaki, K., Eskes, H. J., Sudo, K., Takigawa, M., van Weele, M., and Boersma, K. F.: Simultaneous assimilation of satellite $\mathrm{NO}_{2}$, $\mathrm{O}_{3}, \mathrm{CO}$, and $\mathrm{HNO}_{3}$ data for the analysis of tropospheric chemical composition and emissions, Atmos. Chem. Phys., 12, 95459579, doi:10.5194/acp-12-9545-2012, 2012b.

Nedelec, P., Cammas, J.-P., Thouret, V., Athier, G., Cousin, J.-M., Legrand, C., Abonnel, C., Lecoeur, F., Cayez, G., and Marizy, C.: An improved infrared carbon monoxide analyser for routine measurements aboard commercial Airbus aircraft: technical validation and first scientific results of the MOZAIC III programme, Atmos. Chem. Phys., 3, 1551-1564, doi:10.5194/acp-3-15512003, 2003.

Novelli, P. C. and Masarie, K. A.: Atmospheric Carbon Monoxide Dry Air Mole Fractions from the NOAA ESRL Carbon Cycle Cooperative Global Air Sampling Network, 19882013, version 2014-07-02, available at: ftp://aftp.cmdl.noaa.gov/ data/trace_gases/co/flask/surface/ (last access: December 2014), 2014.

Olivier, J., Peters, J., Granier, C., Petron, G., Müller, J., and Wallens, S.: Present and future surface emissions of atmospheric compounds, POET report \#2, EU project EVK2-1999-00011, available at: http://www.aero.jussieu.fr/projet/ACCENT/POET. php (last access: December 2014), 2003. 
Oltmans, S. J. and Levy II, H.: Surface ozone measurements from a global network, Atmos. Environ., 28, 9-24, 1994.

Parrington, M., Jones, D. B. A., Bowman, K. W., Horowitz, L. W., Thompson, A. M., Tarasick, D. W., and Witte, J. C.: Estimating the summertime tropospheric ozone distribution over North America through assimilation of observations from the Tropospheric Emission Spectrometer, J. Geophys. Res., 113, D18307, doi:10.1029/2007JD009341, 2008.

Parrington, M., Jones, D. B. A., Bowman, K. W., Horowitz, L. W., Thompson, A. M., Tarasick, D. W., Merrill, J., Oltmans, S. J., Leblanc, T., Witte, J. C., and Millet, D. B.: Impact of the assimilation of ozone from the Tropospheric Emission Spectrometer on surface ozone across North America, J. Geophys. Res., 36, L04802, doi:10.1029/2008GL036935, 2009.

Raspollini, P., Carli, B., Carlotti, M., Ceccherini, S., Dehn, A., Dinelli, B. M., Dudhia, A., Flaud, J.-M., López-Puertas, M., Niro, F., Remedios, J. J., Ridolfi, M., Sembhi, H., Sgheri, L., and von Clarmann, T.: Ten years of MIPAS measurements with ESA Level 2 processor V6 - Part 1: Retrieval algorithm and diagnostics of the products, Atmos. Meas. Tech., 6, 2419-2439, doi:10.5194/amt-6-2419-2013, 2013.

Richter, A., Begoin, M., Hilboll, A., and Burrows, J. P.: An improved $\mathrm{NO}_{2}$ retrieval for the GOME-2 satellite instrument, Atmos. Meas. Tech., 4, 1147-1159, doi:10.5194/amt-4-1147-2011, 2011.

Rodgers, C. D.: Inverse methods for atmospheric sounding - theory and practice, Series on Atmospheric, Oceanic and Planetary Physics, World Scientific Publishing, Singapore, 2000.

Sandu, A. and Chai, T.: Chemical data assimilation - An overview, Atmosphere, 2, 426-463; doi:10.3390/atmos2030426, 2011.

Shindell, D. T., Faluvegi, G., Stevenson, D. S., Krol, M. C., Emmons, L. K., Lamarque, J.-F., Pétron, G., Dentener, F. J., Ellingsen, K., Schultz, M. G., Wild, O., Amann, M., Atherton, C. S., Bergmann, D. J., Bey, I., Butler, R., Cofala, J., Collins, W. J., Derwent, R. G., Doherty, R. M., Drevet, J., Eskes, H. J., Fiore, A. M., Gauss, M., Hauglustaine, D. A., Horowitz, L. W., Isaksen, I. S. A., Lawrence, M. G., Montanaro, V., Müller, J.-F., Pitari, G., Prather, M. J., Pyle, J. A., Rast, S., Rodriguez, J. M., Sanderson, M. G., Savage, N. H., Strahan, S. E., Sudo, K., Szopa, S., Unger, N., van Noije, T. P. C., and Zeng, G.: Multi-model simulations of carbon monoxide: comparison with observations and projected near-future changes, J. Geophys. Res., 111, D19306, doi:10.1029/2006JD007100, 2006.

Silver, J. D., Brandt, J., Hvidberg, M., Frydendall, J., and Christensen, J. H.: Assimilation of $\mathrm{OMI} \mathrm{NO}_{2}$ retrievals into the limited-area chemistry-transport model DEHM (V2009.0) with a 3-D OI algorithm, Geosci. Model Dev., 6, 1-16, doi:10.5194/gmd-6-1-2013, 2013.

Škerlak, B., Sprenger, M., and Wernli, H.: A global climatology of stratosphere-troposphere exchange using the ERA-Interim data set from 1979 to 2011, Atmos. Chem. Phys., 14, 913-937, doi:10.5194/acp-14-913-2014, 2014.

Stein, O.: Model documentation of the MOZART CTM as implemented in the GEMS system, available at: http://gems.ecmwf.int/ documents/index.jsp\#grg (last access: December 2014), 2009.

Stein, O., Schultz, M. G., Bouarar, I., Clark, H., Huijnen, V., Gaudel, A., George, M., and Clerbaux, C.: On the wintertime low bias of Northern Hemisphere carbon monoxide found in global model simulations, Atmos. Chem. Phys., 14, 9295-9316, doi:10.5194/acp-14-9295-2014, 2014.

Steinbrecht, W., Shwartz, R., and Claude, H.: New pump correction for the Brewer-Mast ozone sonde: Determination from experiment and instrument intercomparisons, J. Atmos. Ocean. Tech., 15, 144-156, 1998.

Tangborn, A., Stajner, I., Buchwitz, M., Khlystova, I., Pawson, S., Burrows, J., Hudman, R., and Nedelec, P.: Assimilation of SCIAMACHY total column CO observations: Global and regional analysis of data impact, J. Geophys. Res., 114, D07307, doi:10.1029/2008JD010781, 2009.

Tanimoto, H., Sawa, Y., Yonemura, S., Yumimoto, K., Matsueda, H., Uno, I., Hayasaka, T., Mukai, H., Tohjima, Y., Tsuboi, K., and Zhang, L.: Diagnosing recent CO emissions and ozone evolution in East Asia using coordinated surface observations, adjoint inverse modeling, and MOPITT satellite data, Atmos. Chem. Phys., 8, 3867-3880, doi:10.5194/acp-8-3867-2008, 2008.

Valcke, S. and Redler, R.: OASIS4 User Guide (OASIS4\_0\_2). PRISM-Support Initiative, Technical Report No 4, available at: www.prism.enes.org/Publications/Reports/OASIS4_User_ Guide_T4.pdf (last access: December 2014), 2006.

van $\operatorname{der}$ A, R. J., Allaart, M. A. F., and Eskes, H. J.: Multi sensor reanalysis of total ozone, Atmos. Chem. Phys., 10, 11277-11294, doi:10.5194/acp-10-11277-2010, 2010.

van Noije, T. P. C., Eskes, H. J., Dentener, F. J., Stevenson, D. S., Ellingsen, K., Schultz, M. G., Wild, O., Amann, M., Atherton, C. S., Bergmann, D. J., Bey, I., Boersma, K. F., Butler, T., Cofala, J., Drevet, J., Fiore, A. M., Gauss, M., Hauglustaine, D. A., Horowitz, L. W., Isaksen, I. S. A., Krol, M. C., Lamarque, J.-F., Lawrence, M. G., Martin, R. V., Montanaro, V., Müller, J.F., Pitari, G., Prather, M. J., Pyle, J. A., Richter, A., Rodriguez, J. M., Savage, N. H., Strahan, S. E., Sudo, K., Szopa, S., and van Roozendael, M.: Multi-model ensemble simulations of tropospheric $\mathrm{NO}_{2}$ compared with GOME retrievals for the year 2000, Atmos. Chem. Phys., 6, 2943-2979, doi:10.5194/acp-62943-2006, 2006.

Van Roozendael, M., Spurr, R., Loyola, D., Lerot, C., Balis, D., Lambert, J.-C., Zimmer, W., van Gent, J., van Geffen, J., Koukouli, M., Granville, J., Doicu, A., Fayt, C., and Zehner, C.: Sixteen years of GOME/ERS-2 total ozone data: The new direct-fitting GOME Data Processor (GDP) version 5 - Algorithm description, J. Geophys. Res., 117, D03305, doi:10.1029/2011JD016471, 2012.

Vinken, G. C. M., Boersma, K. F., van Donkelaar, A., and Zhang, L.: Constraints on ship $\mathrm{NO}_{\mathrm{x}}$ emissions in Europe using GEOSChem and $\mathrm{OMI}$ satellite $\mathrm{NO}_{2}$ observations, Atmos. Chem. Phys., 14, 1353-1369, doi:10.5194/acp-14-1353-2014, 2014.

von Clarmann, T., Glatthor, N., Grabowski, U., Höpfner, M., Kellmann, S., Kiefer, M., Linden, A., Mengistu Tsidu, G., Milz, M., Steck, T., Stiller, G. P., Wang, D. Y., Fischer, H., Funke, B., Gil-López, S., and López-Puertas, M.: Retrieval of temperature and tangent altitude pointing from limb emission spectra recorded from space by the Michelson Interferometer for Passive Atmospheric Sounding (MIPAS), J. Geophys. Res., 108, 4736, doi:10.1029/2003JD003602, 2003.

von Clarmann, T., Höpfner, M., Kellmann, S., Linden, A., Chauhan, S., Funke, B., Grabowski, U., Glatthor, N., Kiefer, M., Schieferdecker, T., Stiller, G. P., and Versick, S.: Retrieval of temperature, $\mathrm{H}_{2} \mathrm{O}, \mathrm{O}_{3}, \mathrm{HNO}_{3}, \mathrm{CH}_{4}, \mathrm{~N}_{2} \mathrm{O}, \mathrm{ClONO}_{2}$ and $\mathrm{ClO}$ from MIPAS 
reduced resolution nominal mode limb emission measurements, Atmos. Meas. Tech., 2, 159-175, doi:10.5194/amt-2-159-2009, 2009.

Wang, P., Stammes, P., van der A, R., Pinardi, G., and van Roozendael, M.: FRESCO+: an improved $\mathrm{O}_{2}$ A-band cloud retrieval algorithm for tropospheric trace gas retrievals, Atmos. Chem. Phys., 8, 6565-6576, doi:10.5194/acp-8-6565-2008, 2008.

Wang, X., Mallet, V., Berroir, J.-P., and Herlin, I.: Assimilation of OMI NO2 retrievals into a regional chemistry-transport model for improving air quality forecasts over Europe, Amos. Environ., 45, 485-492, 2011.

Waters, J. W., Froidevaux, L., Harwood, R. S., Jarnot, R. F., Pickett, H. M., Read, W. G., Siegel, P. H., Cofield, R. E., Filipiak, M. J., Flower, D. A., Holden, J. R., Lau, G. K., Livesey, N. J., Manney, G. L., Pumphrey, H. C., Santee, M. L., Wu, D. L., Cuddy, D. T., Lay, R. R., Loo, M. S., Perun, V. S., Schwartz, M. J., Stek, P. C., Thurstans, R. P., Boyles, M. A., Chandra, K. M., Chavez, M. C., Chen, G.-S., Chudasama, B. V., Dodge, R., Fuller, R. A., Girard, M. A., Jiang, J. H., Jiang, Y., Knosp, B. W., LaBelle, R. C., Lam, J. C., Lee, K. A., Miller, D., Oswald, J. E., Patel, N. C., Pukala, D. M., Quintero, O., Scaff, D. M., Van Snyder, W., Tope, M. C., Wagner, P. A., and Walch, M. J.: The Earth Observing System Microwave Limb Sounder (EOS MLS) on the Aura satellite, IEEE Trans. Geosci. Remote Sens., 44, 1075-1092, 2006.

WHO: Burden of disease from Household Air Pollution for 2012, http://www.who.int/phe/health_topics/outdoorair/databases/ FINAL_HAP_AAP_BoD_24March2014.pdf (last access: December 2014), 2014.

Williams, J. E., van Velthoven, P. F. J., and Brenninkmeijer, C. A. M.: Quantifying the uncertainty in simulating global tropospheric composition due to the variability in global emission estimates of Biogenic Volatile Organic Compounds, Atmos. Chem. Phys., 13, 2857-2891, doi:10.5194/acp-13-2857-2013, 2013.
Yarwood, G., Rao, S., Yocke, M., and Whitten, G. Z.: Updates to the Carbon Bond Mechanism: CB05. US EPA Final Report, 161 p., available at: http://www.camx.com/publ/pdfs/CB05_Final_ Report_120805.pdf (last access: December 2014), 2005.

Young, P. J., Archibald, A. T., Bowman, K. W., Lamarque, J.-F., Naik, V., Stevenson, D. S., Tilmes, S., Voulgarakis, A., Wild, O., Bergmann, D., Cameron-Smith, P., Cionni, I., Collins, W. J., Dalsøren, S. B., Doherty, R. M., Eyring, V., Faluvegi, G., Horowitz, L. W., Josse, B., Lee, Y. H., MacKenzie, I. A., Nagashima, T., Plummer, D. A., Righi, M., Rumbold, S. T., Skeie, R. B., Shindell, D. T., Strode, S. A., Sudo, K., Szopa, S., and Zeng, G.: Preindustrial to end 21 st century projections of tropospheric ozone from the Atmospheric Chemistry and Climate Model Intercomparison Project (ACCMIP), Atmos. Chem. Phys., 13, 2063 2090, doi:10.5194/acp-13-2063-2013, 2013.

Yudin, V. A., Pétron, G., Lamarque, J.-F., Khattatov, B. V., Hess, P. G., Lyjak, L. V., Gille, J. C., Edwards, D. P., Deeter, M. N., and Emmons, L. K.: Assimilation of the 2000-2001 CO MOPITT retrievals with optimized surface emissions, Geophys. Res. Lett., 31, L20105, doi:10.1029/2004GL021037, 2004.

Zhang, Y., Bocquet, M., Mallet, V., Seigneur, C., and Baklanov, A.: Real-time air quality forecasting, part II: State of the science, current research needs, and future prospects, Atmos. Environ., 60, 656-676, 2012. 